براورد آب مورد نياز و ضرايبگياهى استويا (Stevia rebaudiana Bertoni) در اقليم نيمه خشك در شرايط لايسيمترى

زهرا جليلى'، هوشنگ قمرنيا 'و دانيال كهريزى'

(تاريخ دريافت: D// /

جكيده

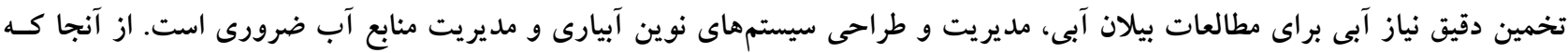

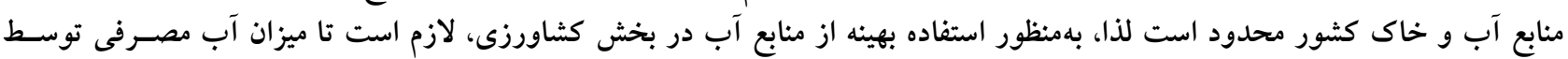

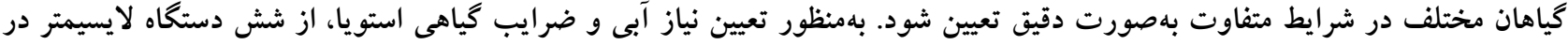

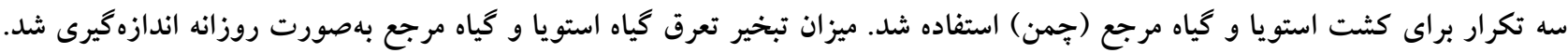

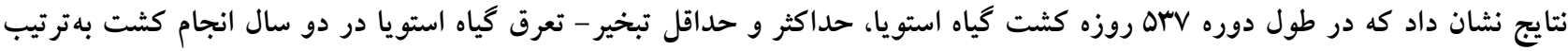

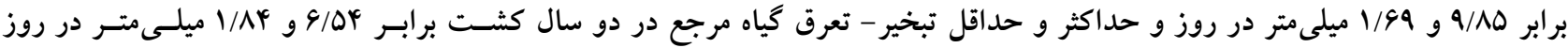

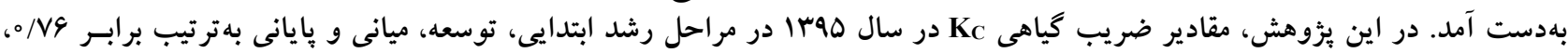

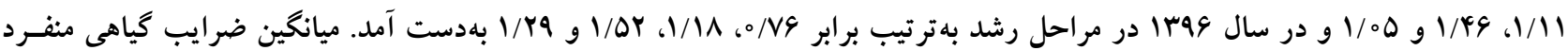

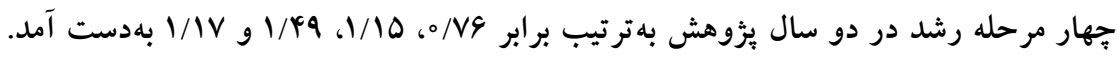

وازههاى كليدى: تبخير - تعرق، گياه مرجع، مزرعه تحقيقاتى، استويا

ا. كروه مهندسى آب، يرديس كشاورزى و منابع طبيعى، دانشخاه رازى، كرمانشاه r. كروه زراعت، برديس كشاورزى و منابع طبيعى، دانشخاه رازى، كرمانشاه

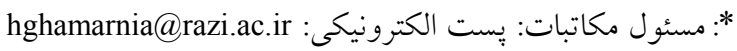




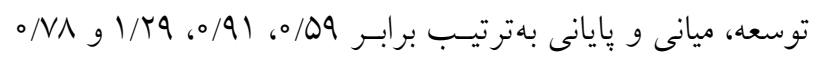

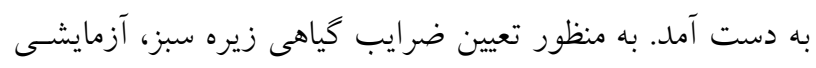

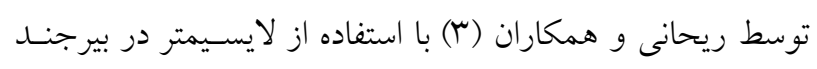

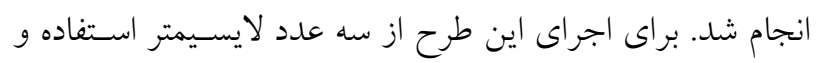

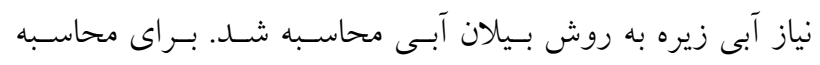

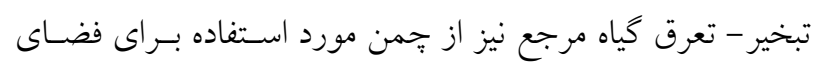

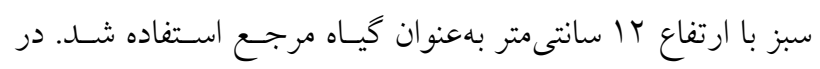
نهايت در بايان فصل رشد، مقادير مربوط به ضرايب گياهى زيـره

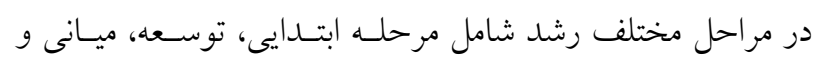

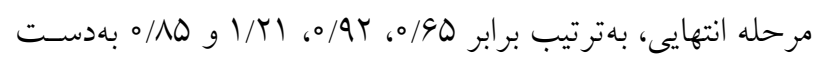

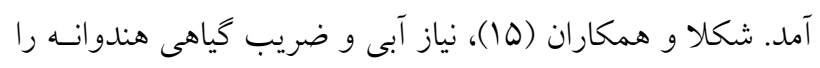

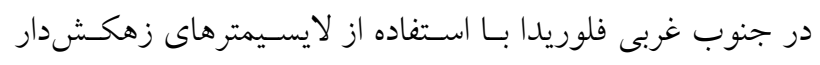

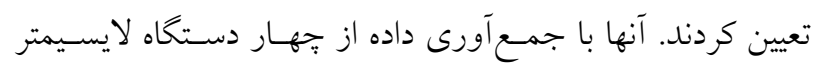

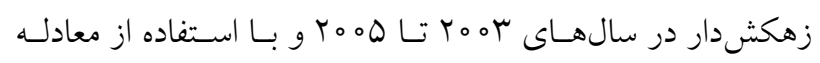

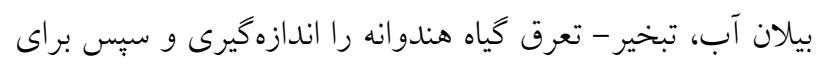

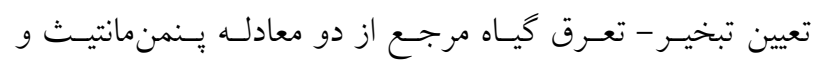

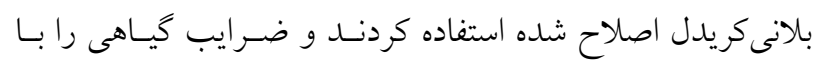

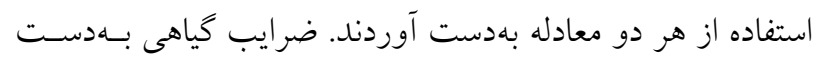

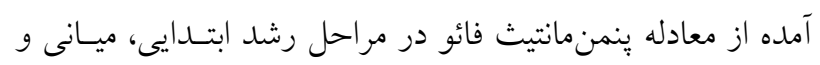

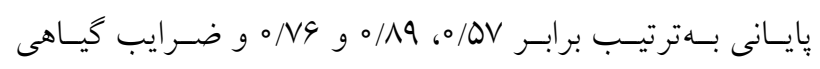

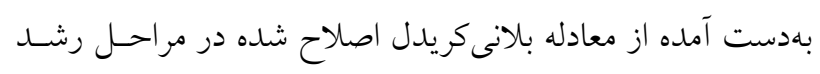

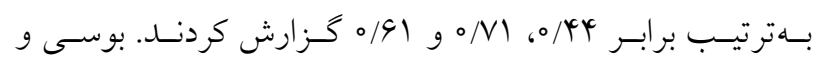

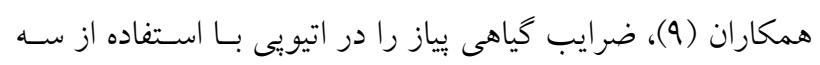

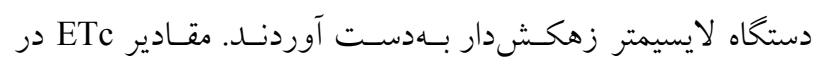

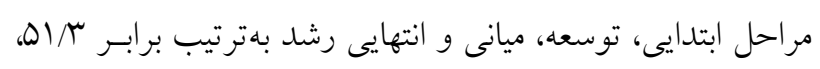

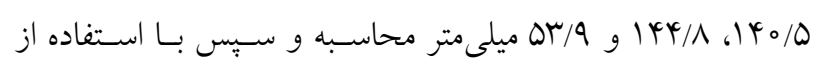

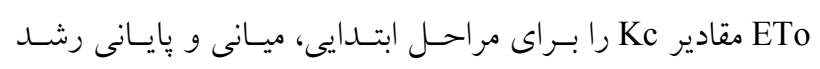

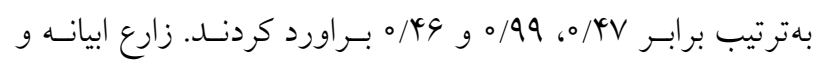

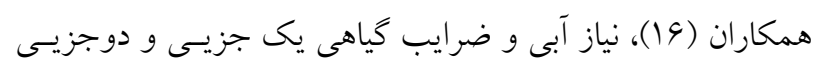

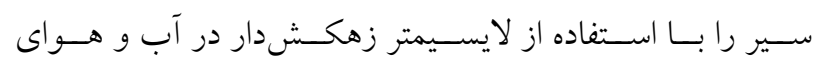

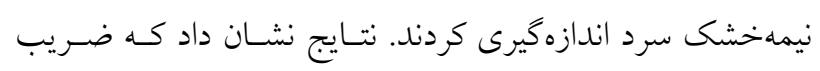

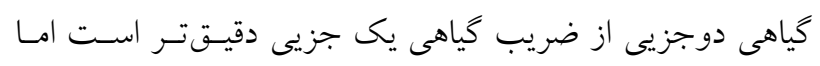

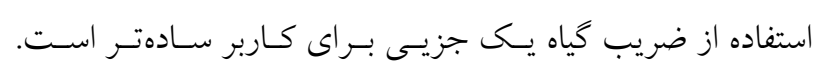

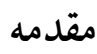

در سال هاى اخير كمبود بارندگى، آب را بـه يكسى از مهـمتـرين

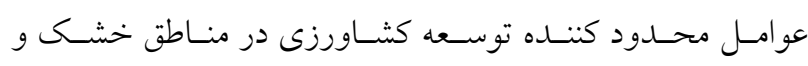

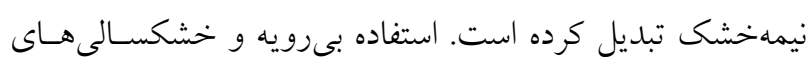

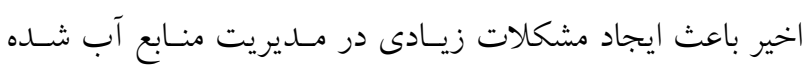

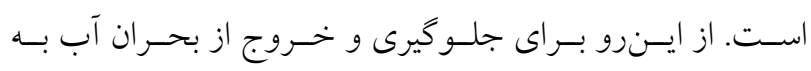

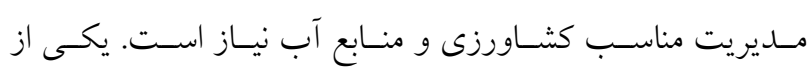

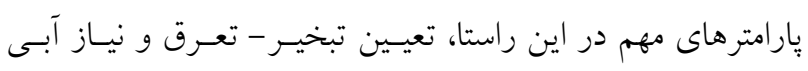

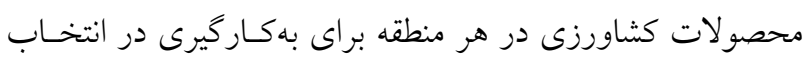

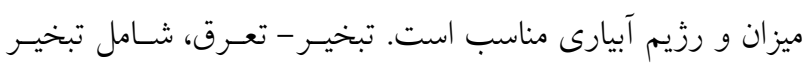

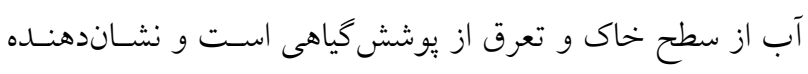

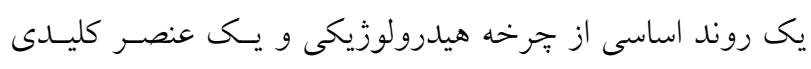

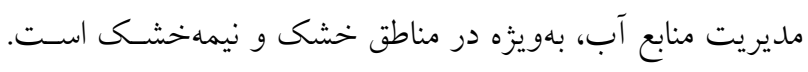

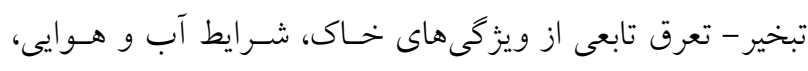

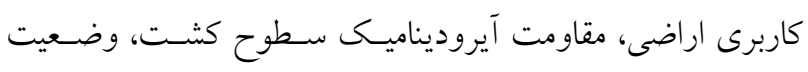

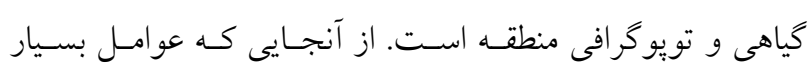

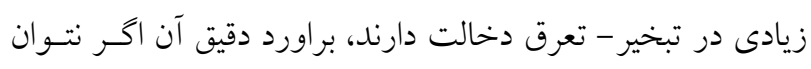

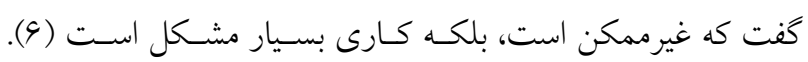

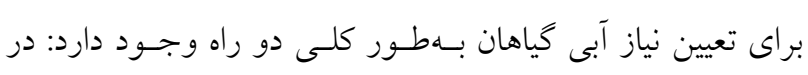

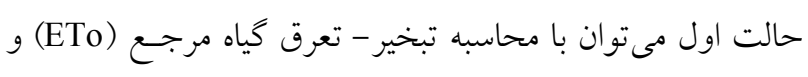

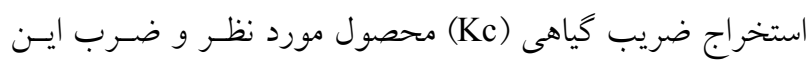

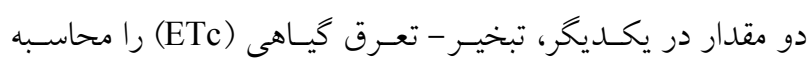

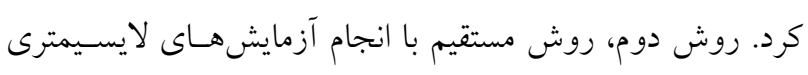

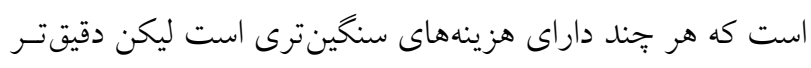

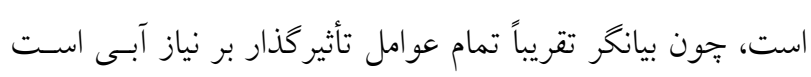

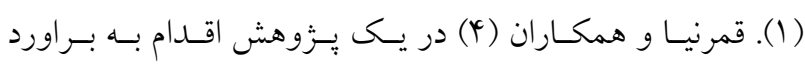

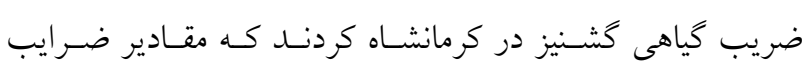

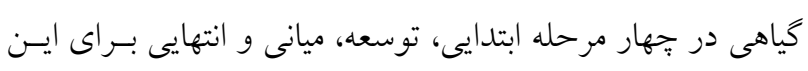

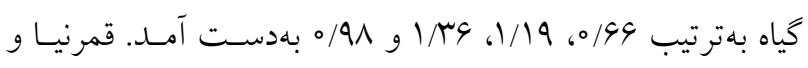
همكاران (ه) در مطالعه ديخرى ضريب رشد كيـاهى سـياهدانسه را در مراحل مختلف رشد به روش لايسيمترى تعيين كردنـا، نتـايج

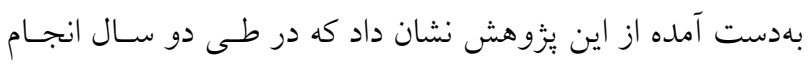

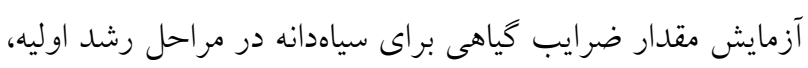




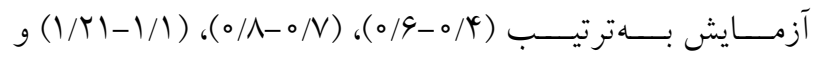

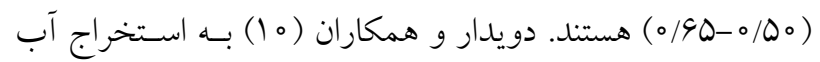
مورد نياز و ضرايب گياهى خرما با استفاده از لايسيمتر زهكشدار

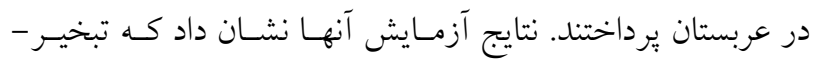

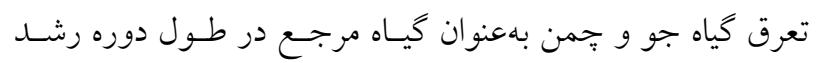

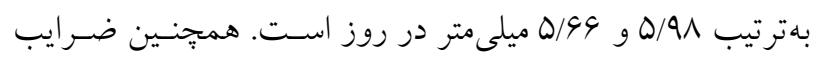

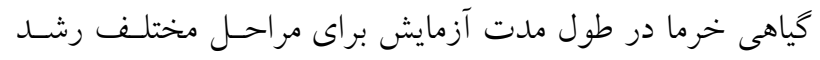

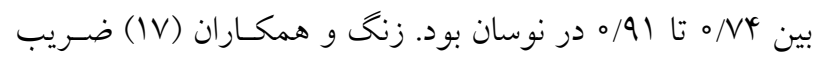
كياهى گندم زمستانه را با استفاده از روش آبيارى ثقلى در شـمال جين براورد كردند. نتايج آزمايش آنها نشان داد كه مقادير ضـريب

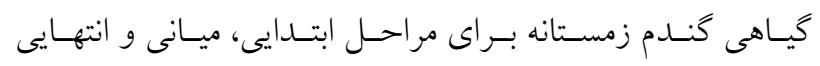

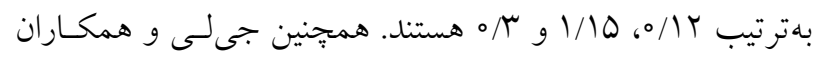

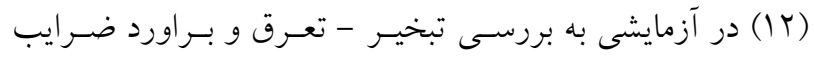
كياهى كندم زمستانه در جين برداختند. نتايج نشان داد كـه مقـدار

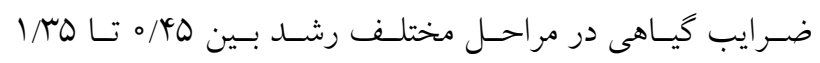
بهدست آمد كه مقدار متوسط آن در طول دوره رشد برابر با 99/ه است. فرونـزا و وينيشـيوس فوليخـاتى (1) آزمايشـى بـهمنظـور بررسى مقدار آب مورد نياز براى رشد محصول استويا و تـأثير آن بر عملكرد اين كياه در شرايط استفاده از ميكرولايسيمتر بـا سـطح

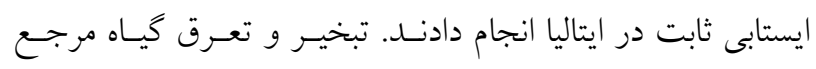
توسط معادله ينمن مانتيـث تخمـين زده شـــ و سـطح آب نيـز در عمق 90 سانتى مترى ثابت شده بود. نتايج آزمـايش نشـان داد كـه

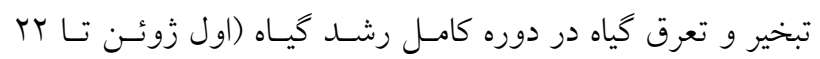

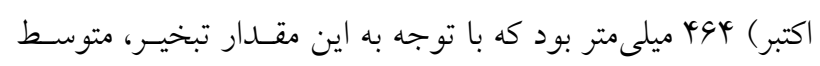

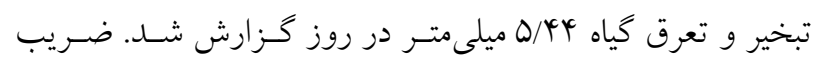
كياهى در هr روز اول رشد گياه ه广/1، در مرحله ميـانى (روز צr

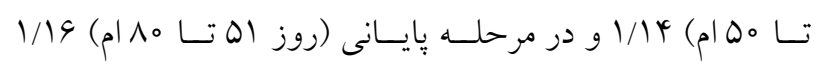
بهدست آمد. كياه مورد بررسى در اين يزّوهش، گياه استويا با نـام

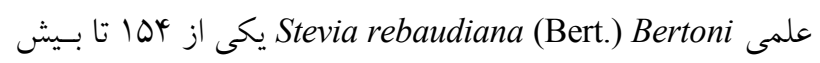

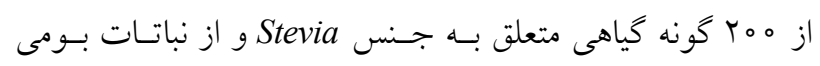
كشور يار اكوئه است كه داراى شيرين كندههــاى طبيعى عـارى از كالرى است. گياه استويا به علل متعددى از قبيل سـاز گارى بسـيار بالا به محدوده وسيعى از شرايط مختلف اقليمى، محتـواى بـالاى
رحيميان و كاخكى (T)، نياز آبى و ضريب گياهى ينبه را به روش

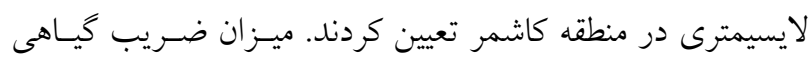

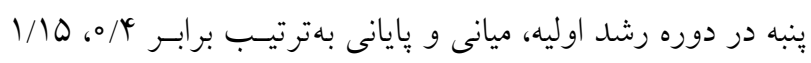

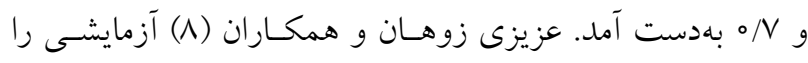
طى دو سال متوالى براى تعيين ضرايب گياهى زعفران با اسـتفاده

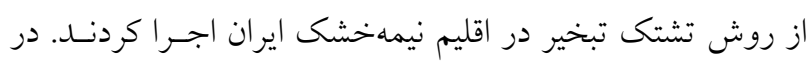
اين يزوهش براى محاسبه ETo از معادله ينمن مانتيث فائو استفاده

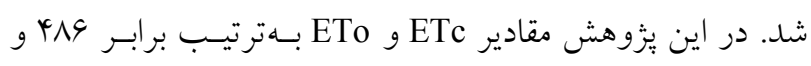
991 ميلى متر در سال اول آزمايش و 9V0 و هVQ ميلىمتر در سال

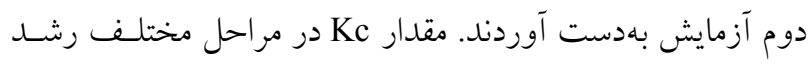

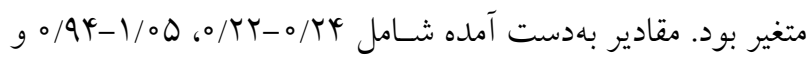
ه/91_- o/VA

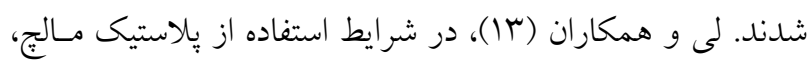
نياز آبى و ضرايب كياهى ذرت بهـاره را در منطقـه شـمال غـرب جين براورد كردند. در اين يزوهش براى اندازهيرى يارامترهـا از

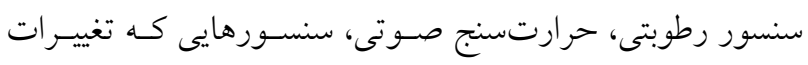
عمودى باد، دما و جِحالى آب را اندازه مسى گيرنــ، اسـتفاده شــد.

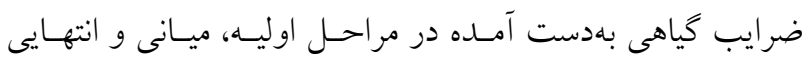

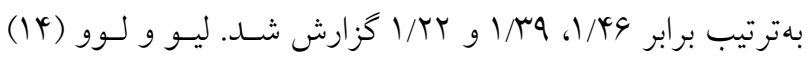
ضرايب كياهى دو كانه براى ذرت تابسـتانه و كنــدم يــاييزه راكـهـ توسط FAOD9 در منطقة شمال جين گزارش شده بود، ارزيابى و بررسى كردند. نتايج نشان داد كه روش استفاده از ضرايب گيـاهى دو جزئسى بــراى دو محصــول يـــيرفتنى اسـت، امــا بــراى دوره حداكثر نتايج غلطى ارائه مى دهد. آنها يِشنهاد كردنــ كـه مقـادير ضرايب گياهى بايه طى دورههاى اوليه، ميـانى و بايـانى بــراى دو محصول بايد اصلاح شود. مقادير ضـرايب گيـاهى بــراورد شــه توسط لايسيمتر طى دورههاى رشد شامل اوليه، توسـعه، ميـانى و

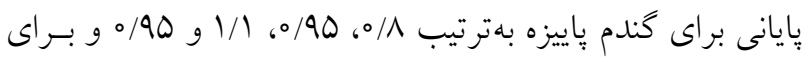
ذرت تابستانه بهترتيب 9/9، سو/ه، ه/ ا و ا بـراى منطقـه مـورد

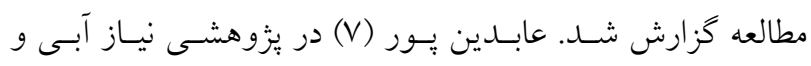

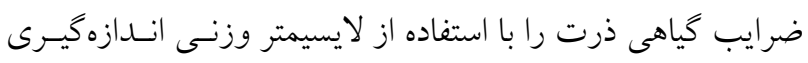
كرد. نتايج بزوهش او نشان داد كه ضـرايب گيـاهى ذرت دانسهاى در دوره ابتدايى، توسعه، ميانى و انتهايى رشــ در دو سـال انجـام 
مترى از سطح دريا قـرار كرفتـه استـ. در طـى مــدت انجـام

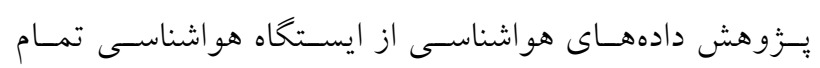

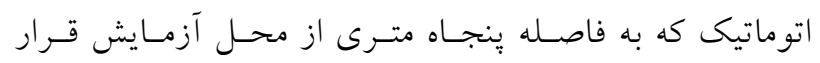

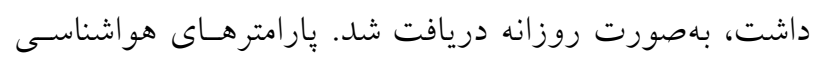

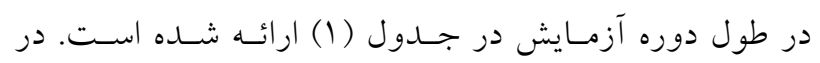

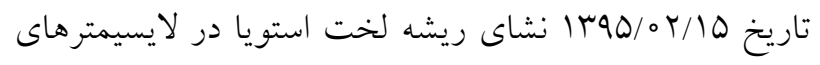

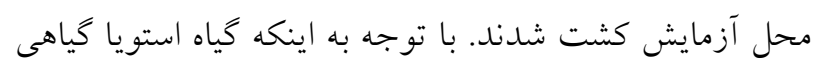

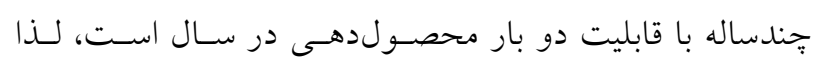

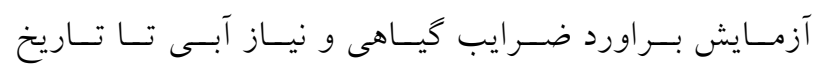

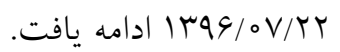
با نمونه كيرىهايى كه در خاكهـاى منطقـه صـورت كرفتـه

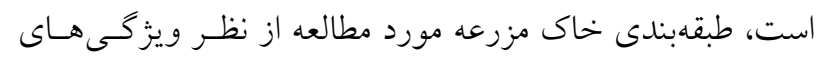

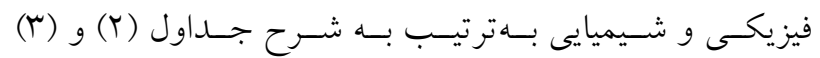

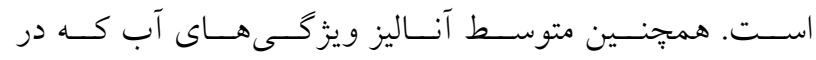

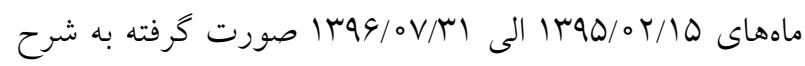

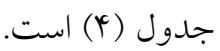

\section{روش محاسبه نياز آبى و ضرايب گياهى}

در اين يزوهش براى محاسبه تبخير - تعرق گياه استويا و كيـاه

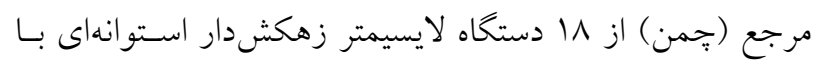

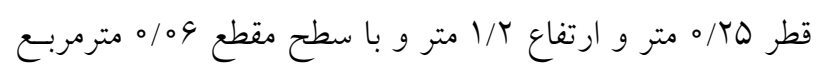

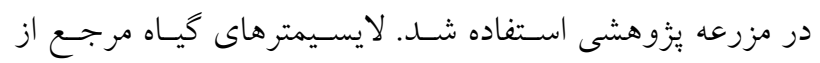
جنس سيمانى بودند و لايسيمترهاى ديخر (كشت كيـاه استويا)

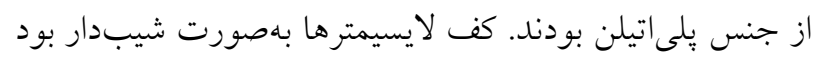

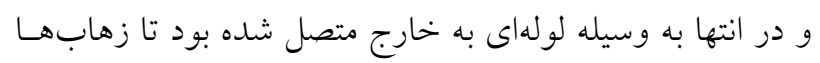

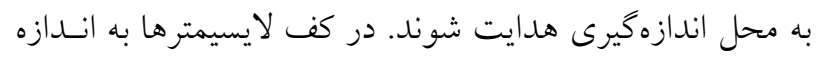

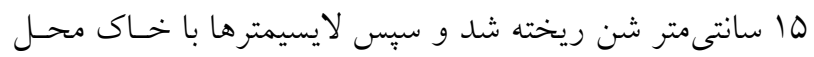

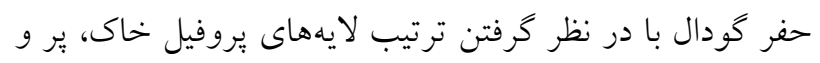

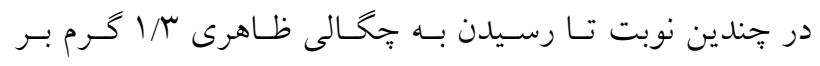
سانتى متر مكعب فشرده شد. براى تحكسيم خـاك قبـل از انجـام

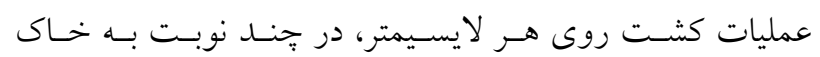
درون مربوطـهـ آب داده شـــ و يـس از نشســت كامـل دوبــاره

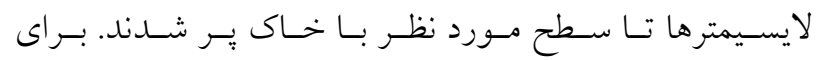

شيرين كنندهاى طبيعى قابل استحصال و نقش جشمخيرى كـه در

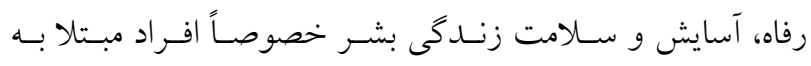

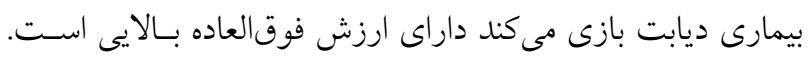

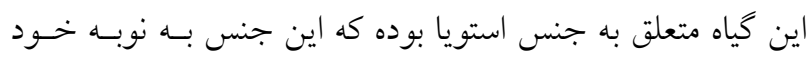

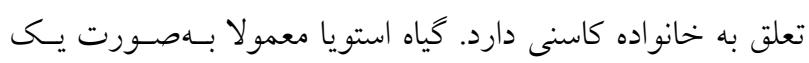

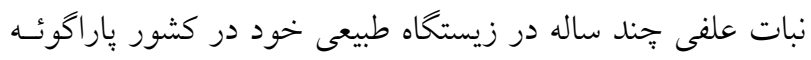

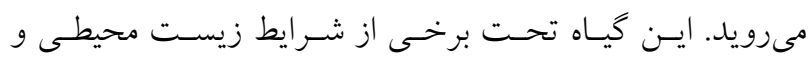

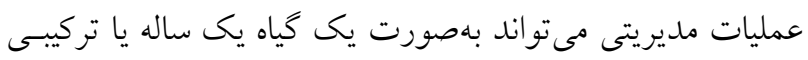

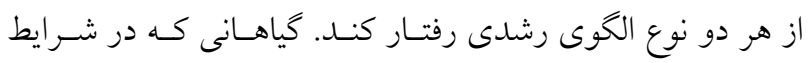

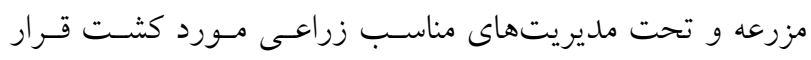

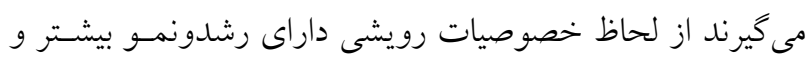

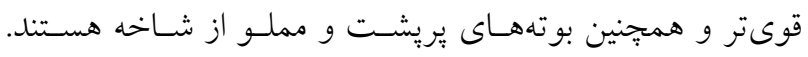

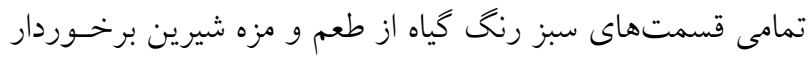

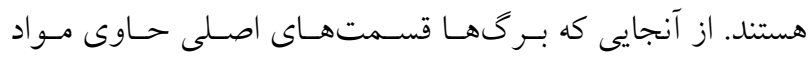

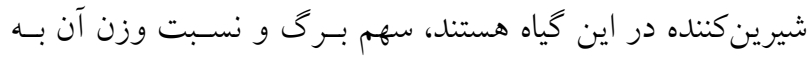

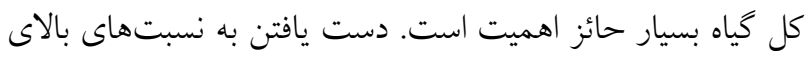

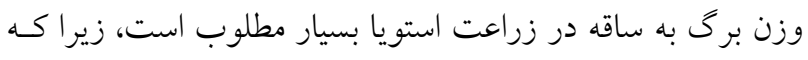

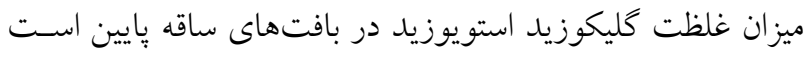

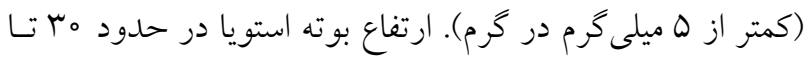

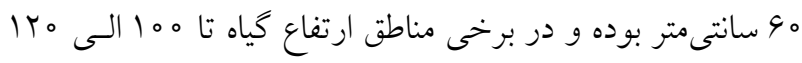

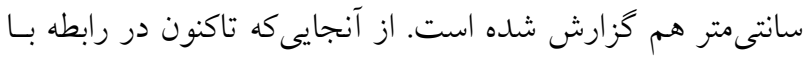

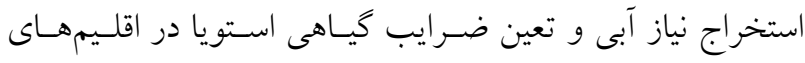

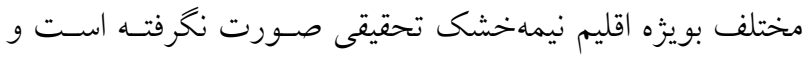

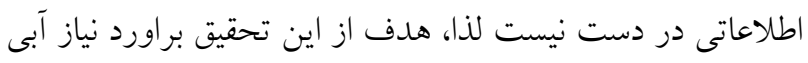

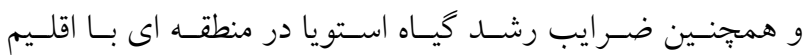
نيمهنش است.

\section{مواد و روشها}

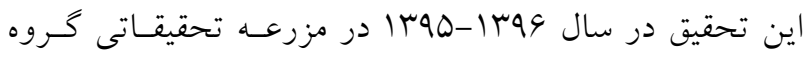
مهندسى آب واقـع در پــرديس دانشـكده كشـاورزى و منـابع

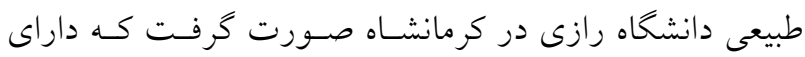

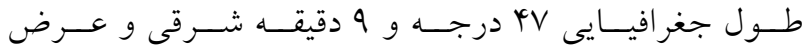

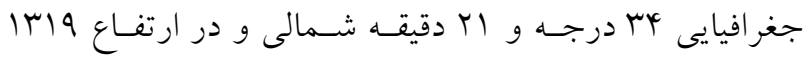


جدول 1. ميانگين پارامترهاى هواشناسى در طى مدت كشت

\begin{tabular}{|c|c|c|c|c|c|c|c|c|}
\hline بارندكى ماهانه & ساعات آفتابى & رطوبت حداقل & 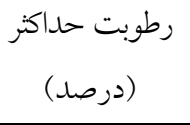 & 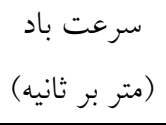 & 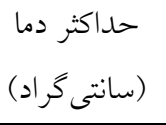 & 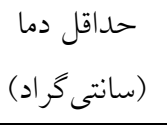 & ماه & سال \\
\hline $1 / 0 \circ$ & $\Lambda / 9 \Lambda$ & Q/Ar & $00 / 09$ & $T / Q V$ & $r Q / \mathcal{T}$ & $1 \mathrm{~V} / 0 \circ$ & ارديبهشت & \\
\hline $0 / 01$ & $10 / V_{0}$ & $0 / 1 \circ$ & $r 9 / 0 \wedge$ & $Y / 91$ & 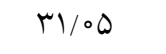 & $11 / 01$ & خرداد & \\
\hline$\%$ & $10 / \mu q$ & $\varphi / \Delta \Lambda$ & $r Q / \circ G$ & T/M & MN/GQ & $|V / T|$ & تير & \\
\hline$\% \circ$ & $11 / r_{0}$ & $r / 94$ & $T Y / \Psi \wedge$ & $r / \Delta \omega$ & $r q / \mu q$ & $|V / I|$ & مرداد & \\
\hline$\circ / \circ \circ$ & $9 / \mathrm{V}$ & $1 / 19$ & TI/AY & $T / Y Q D$ & re/04 & $14 / v q$ & شهريور & \\
\hline$\circ / \circ \circ$ & $1 / 19$ & IT/KT & $r v / q \circ$ & $r / T \Lambda$ & rN/KG & $\wedge / 11$ & مهر & 1490 \\
\hline$\circ / \circ$ & $0 / 99$ & سT/TK & $M / Y_{0}$ & $r / Y I$ & TY/AY & $Q / Y Q$ & آبان & \\
\hline $0 / 4 \wedge$ & $9 / 49$ & $|y| / 0 r$ & $\Lambda V / 4 \circ$ & $r / T 1$ & $11 / v 9$ & -l/Ar & آذر & \\
\hline$r / D 1$ & $D / 41$ & HN/FV & $\Lambda \circ / 9 \mu$ & $r / \circ r$ & $11 / 00$ & $-0 / 19$ & دى & \\
\hline$r / 99$ & $9 / \mu \circ$ & MY/Ar & $\Lambda T / 9 V$ & T/M & $V / T_{0}$ & $-r / 4 r$ & بهمن & \\
\hline سח/T & G/VQ & TN/QV & $\vee q / Y \circ$ & $1 / v 9$ & $\mid Y / \Delta Y$ & $-0 / 41$ & اسفند & \\
\hline Y/TI & $0 / 99$ & MI/Tg & $11 / 19$ & T/T & IV/VT & $G / T Q$ & فروردين & \\
\hline$\circ / N 1$ & $9 / 14$ & IN/TG & $V \pi / 4 D$ & T/YG & $r G / 01$ & $9 / 49$ & ارديبهشت & \\
\hline$\circ / \circ \circ$ & $11 / 09$ & $Q / 9 V$ & $Y Y / T G$ & T/VQ & $M Y / \Delta Q$ & $11 / 99$ & خرداد & \\
\hline$\circ / \circ \circ$ & $11 / 91$ & $r / \varphi \Delta$ & $r \varphi / 4 D$ & T/TG & "N/I & $1 \mathrm{~V} / 9 \mathrm{~V}$ & تير & 1 1ra \\
\hline$\circ / \circ \circ$ & $11 / \mu_{1}$ & & TI/rd & $r / T q$ & $r q / T \varphi$ & $1 N / V^{c}$ & مرداد & \\
\hline$\circ / \circ \circ$ & $9 / T 9$ & $r / \Lambda 1$ & $r \circ / / 4$ & $r / 1 Y$ & $\left|N / \varphi^{c}\right|$ & $|N / T|$ & شهريور & \\
\hline$\% / 00$ & $q / 1 V$ & $r / 1 T$ & $r \mid / T$ & $r / 11$ & & IV/Dr & مهر & \\
\hline
\end{tabular}

جدول r. ويزّكىهاى فيزيكى خاك منطقه مورد مطالعه

\begin{tabular}{|c|c|c|c|c|c|}
\hline Clay & Silt & Sand & \multirow{2}{*}{$\begin{array}{c}\text { عمق نمونه كيرى } \\
(\mathrm{cm})\end{array}$} & \multirow{2}{*}{$\begin{array}{c}\text { وزن مخصوص ظاهرى } \\
\left(\mathrm{gr} / \mathrm{cm}^{r}\right)\end{array}$} & \multirow{2}{*}{ افت خاك } \\
\hline & $(\%)$ & & & & \\
\hline $01 / 9$ & 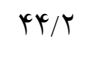 & $\varphi / r$ & $\circ-r_{0}$ & $1 / \mu$ & لتى \\
\hline $0 \circ / 9$ & $49 / 0$ & $r / q$ & $\mu_{0}-90$ & $1 / N T$ & ىسيلتى \\
\hline$\Delta T / V$ & $r \mu / l$ & $r / r$ & $9 \circ-100$ & $1 / M Y$ & رسى سيلتى \\
\hline
\end{tabular}

جدول r. ويزگى هاى شيميايى خاك منطقه مورد مطالعه

\begin{tabular}{|c|c|c|c|c|c|c|c|}
\hline $\mathrm{Zn}$ & $\mathrm{Fe}$ & $\mathrm{Mn}$ & & يتاسيم قابل جذب & فسفر قابل جذب & \multirow{2}{*}{$\begin{array}{c}\mathrm{EC} \\
(\mathrm{dS} / \mathrm{m})\end{array}$} & \multirow{2}{*}{$\mathrm{pH}$} \\
\hline & $(\mathrm{meq} / \mathrm{L})$ & & $(\%)$ & \multicolumn{2}{|c|}{ (ppm) } & & \\
\hline $1 / 79$ & $11 / 9$ & $\mathrm{~V} / \mathrm{A}$ & I/N & pyo & TG & $1 / r$ & $V / r$ \\
\hline
\end{tabular}


جدول f. خصوصيات شيميايى آب منطقه مورد مطالعه

\begin{tabular}{|c|c|c|c|c|c|c|c|c|c|c|c|c|}
\hline \multirow[t]{2}{*}{ SAR } & درصد سديم & كاتيونهاع & $\mathrm{Na}^{+}$ & $\underset{\mathrm{Ca}^{++}}{\mathrm{Mg}^{++}+}$ & آنيونهاع & $\mathrm{SO}_{\varphi}-{ }^{-}$ & $\mathrm{CL}^{-}$ & $\mathrm{HCO}_{r-}^{-}$ & $\mathrm{CO}_{r}{ }^{--}$ & \multirow[t]{2}{*}{$\mathrm{pH}$} & \multirow{2}{*}{$\begin{array}{c}\text { TDS } \\
(\mathrm{mg} / \mathrm{L})\end{array}$} & شآب \\
\hline & & \multicolumn{8}{|c|}{$(\mathrm{meq} / \mathrm{L})$} & & & $(\mathrm{dS} / \mathrm{m})$ \\
\hline $0 / \Delta 4$ & $11 / \mathrm{V}$ & $9 / r^{2}$ & $1 / 09$ & $N / 1 \Lambda$ & $9 / \Gamma \Lambda$ & $1 / 10$ & $1 / 1$ & $9 / \pi^{\circ}$ & 0101 & $9 / 9$ & 941 & 1 \\
\hline
\end{tabular}

نظر كرفتن آستانه تحمل كَياه به دورههاى آبيـارى). زهـاب قبـل از

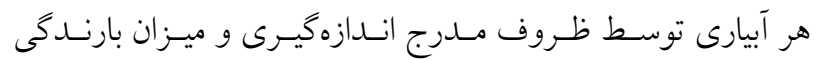

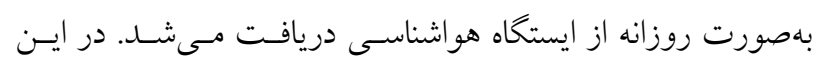
يزوهش اندازهيرى رطوبت در دور آبيـارى بـا استفاده از دستيكاه

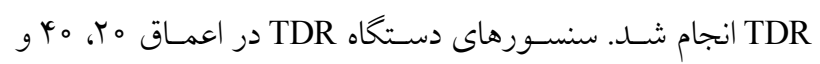

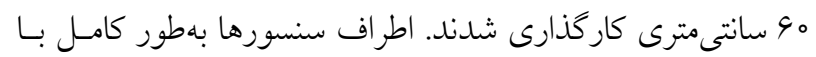

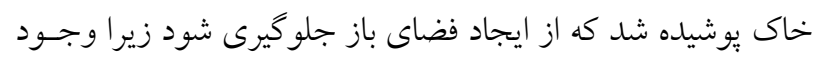
درز هوا قرائتها را تحت تأثير قرار مى داد (شكل (1).

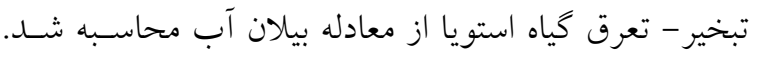

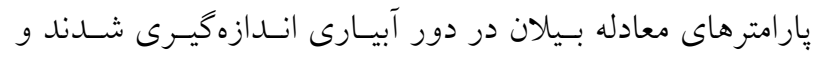

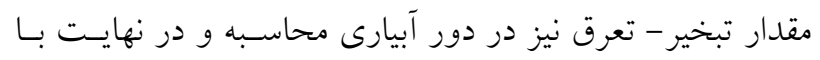
تقسيم آن بر تعداد روزهاى موجود در دور تبخير - تعـرق كيـاه

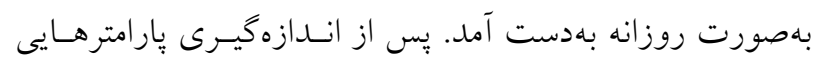
نظير تبخير - تعرق كيـاه مرجـع و تبخيـر - تعـرق كيـاه اسـتويا

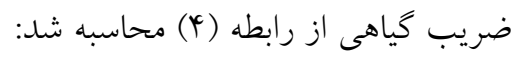

$\mathrm{K}_{\mathrm{C}}=\frac{\mathrm{ET}_{\mathrm{C}}}{\mathrm{ET}_{\mathrm{O}}}$

كه در آن بارامترهاى Kc ضـريب كيـاهى، ETc تبخيـر - تعـرق

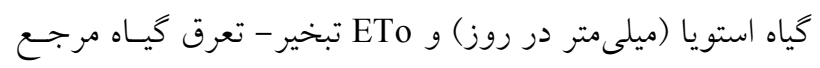

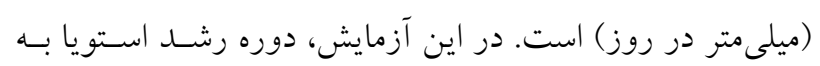

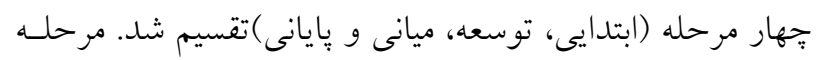

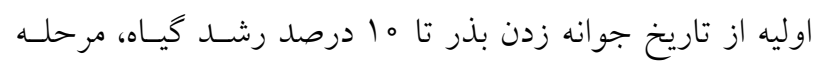
توسعه از ه ا درصد رشد تا شروع گل دههى، مرحله ميانى ازآغاز

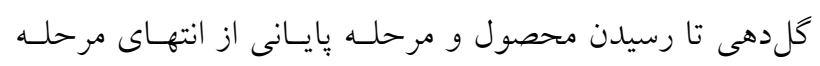
ميانى تا برداشت محصول در نظر كرفته شــــ در طـى دو سـال

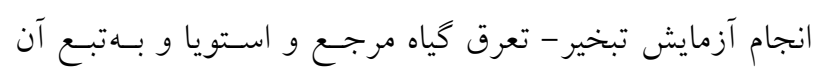

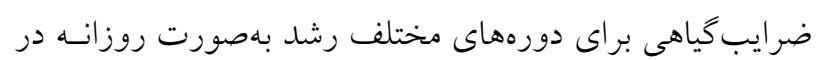
محيط مزرعه تحقيقاتى بهدست آمدائ دورهاى مختاف
اندازهيرى تبخير - تعرق كياه توسط لايسيمتر زهكشدار براى

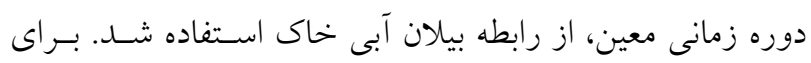

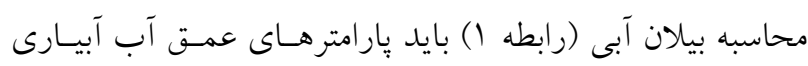

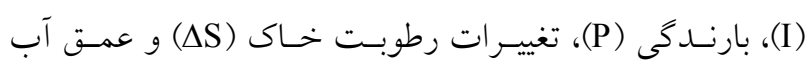

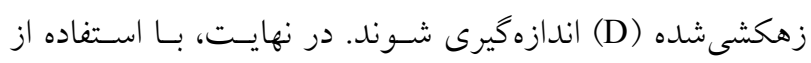

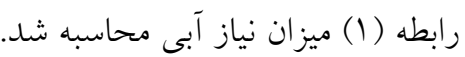

$\mathrm{ETC}=\mathrm{P}+\mathrm{I}-\mathrm{D} \pm \Delta \mathrm{S}$

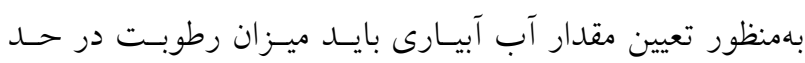

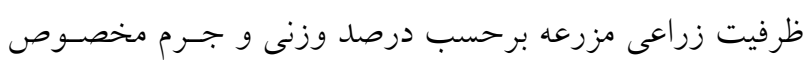
ظاهرى خاك مشـخص شـود. ميـزان عمـق آب آبيـارى در هـر

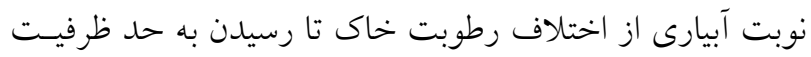

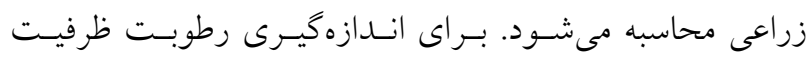

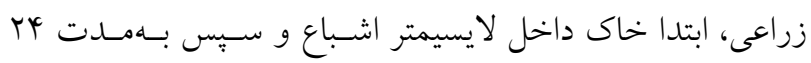

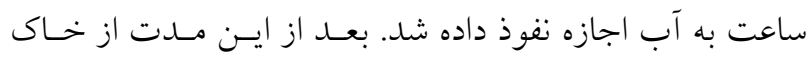

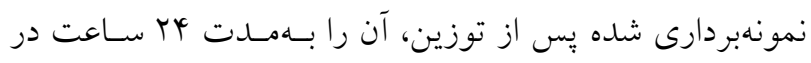

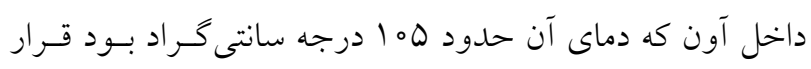

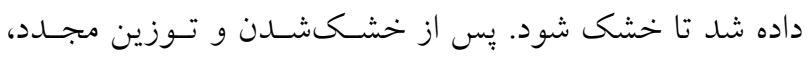

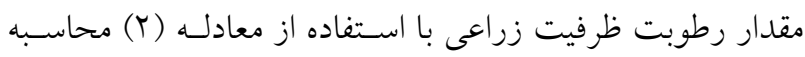

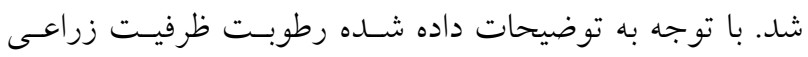

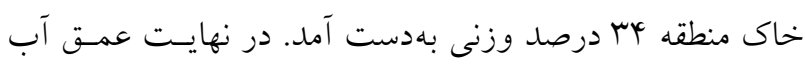
آبيارى (Id) از رابطه (r) محاسبه شد:

$\mathrm{dn}=\left(\theta_{\mathrm{fc}}-\theta_{\mathrm{m}}\right) \times \rho_{\mathrm{b}} \times \mathrm{D} \times \mathrm{MAD}$ كـهـ در آن بارامترهـاى

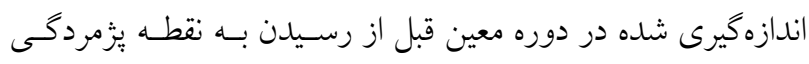

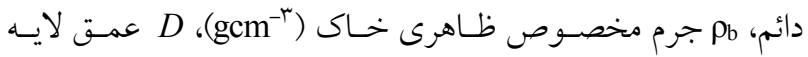
خاك و MAD درصد تخليه مجاز رطوبتى است. در ايسن ي-رؤشش

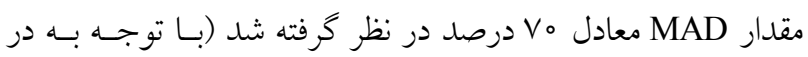




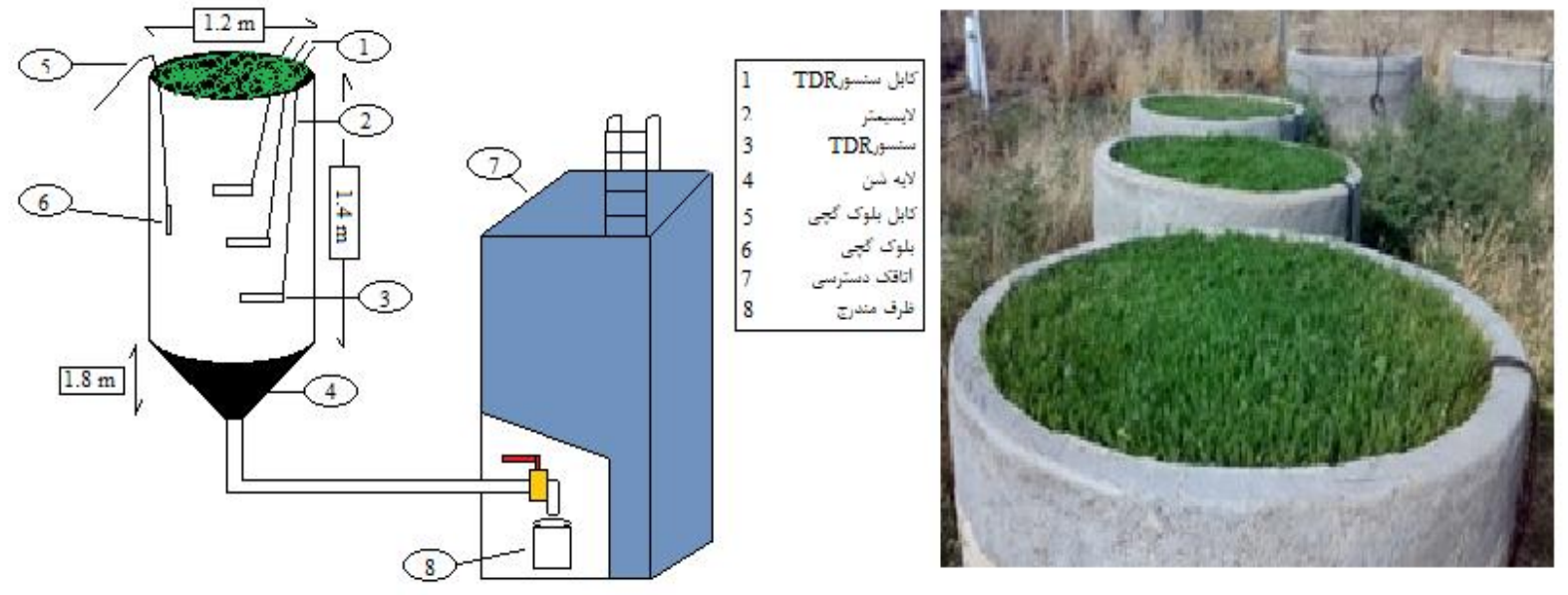

شكل ا.اندازه گيرى تبخير - تعرق گياه استويا و گياه مرجع با استفاده از لايسيمتر زهكشدار

اندام هوايى گياه تبخير - تعرق، افزايش يافته و سِّ در ماههـاى

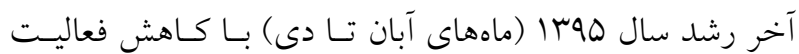

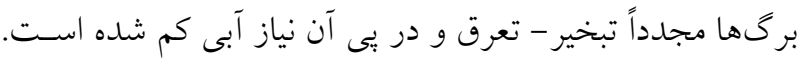

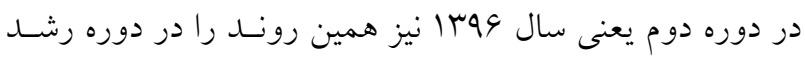

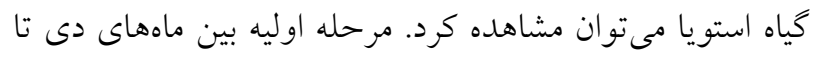

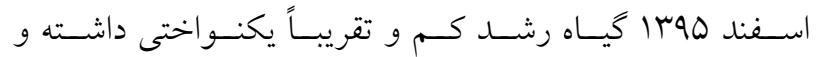

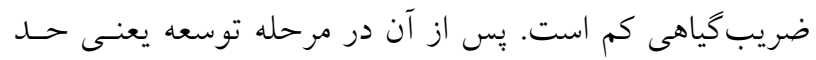

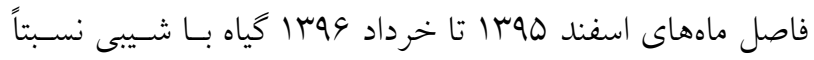

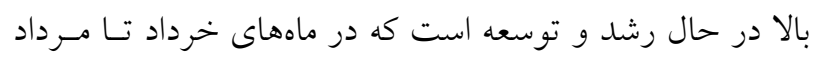
و 9 ا وارد مرحله ميانى با رشد ثابت شده است.

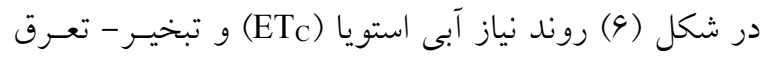

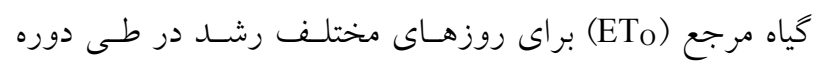

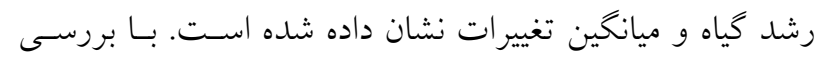
اين شكل در جدول (ه) ميزان حداقل و حداكثر نياز آبسى كيـاه

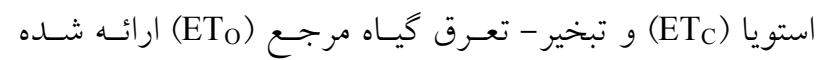

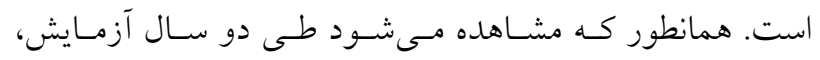

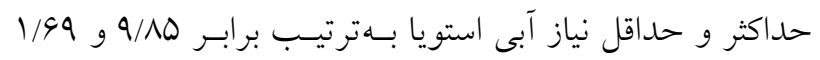

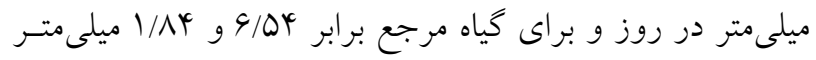
در روز بهدست آمده است. همانطور كه در شكل (9) نشان داده

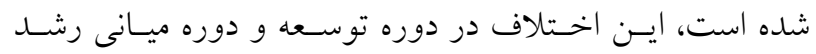

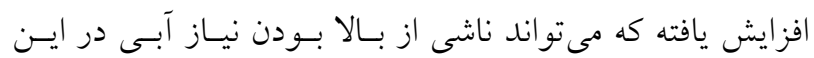

نتايج و بحث

در شكل (Y) ميـزان تبخيـر - تعـرق كيـاه مرجـع در سـالهـاى

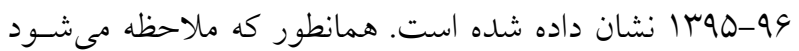

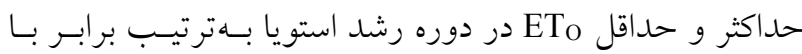

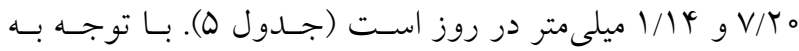

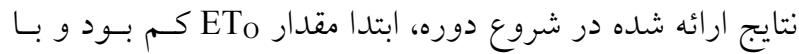
كذشت زمان مقدار آن افزايش مىيابد كه اين افزايش بهدليل بلند بودن طول روز و افزايش تابش خالص خورشيدى است. در شكل (r) تغييرات رطوبـت نسـبى و دمـا در سـالهـاى 99-90

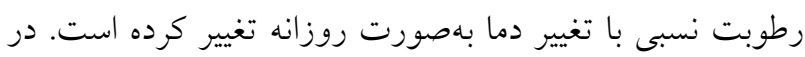

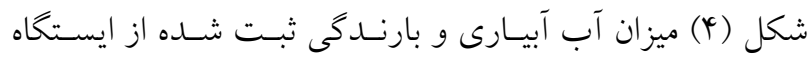

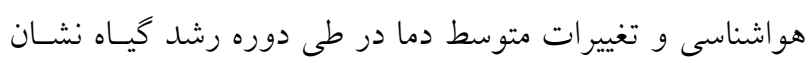

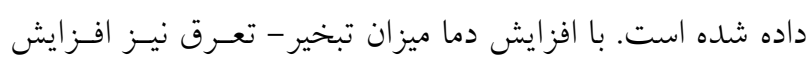

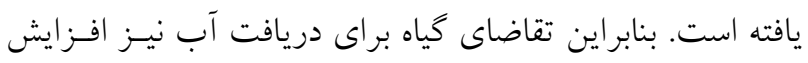

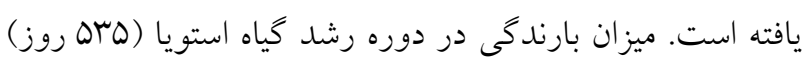

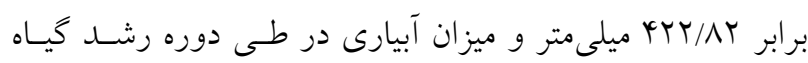

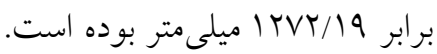

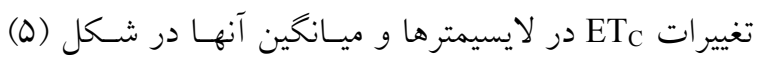
ارائه شده است. در ماه اول كشت بهدليل رشد كم كياه نياز آبى از

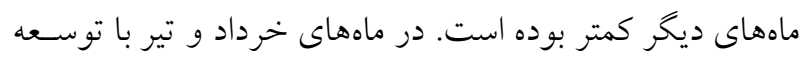




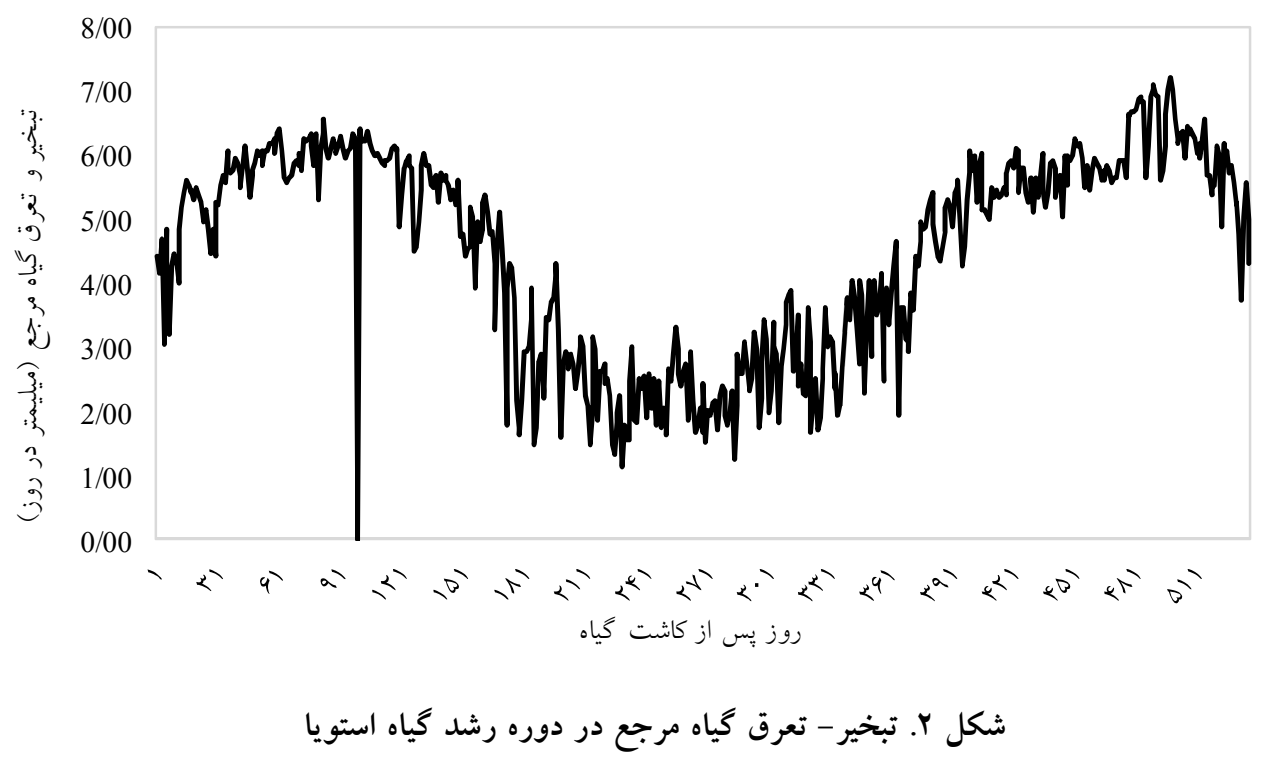

جدول ه. مقادير حداكثر و حداقل تبخير-تعرق گياه استويا از لايسيمتر (ETC) و گياه مرجع (ETo) در دوره رشد گياه استويا (mm d)

\begin{tabular}{|c|c|c|c|c|}
\hline \multicolumn{2}{|c|}{$\mathrm{ET}_{\mathrm{o}}(\mathrm{mm} / \mathrm{day})$} & \multicolumn{2}{|c|}{$\mathrm{ETC}_{\mathrm{C}}(\mathrm{mm} /$ day $)$} & \multirow{2}{*}{ سال } \\
\hline حداقل & حداكثر & حداقل & حداكثر & \\
\hline $1 / v 9$ & $9 / 19$ & $1 / 11$ & $q / T_{0}$ & 1790 \\
\hline $1 / M \Lambda$ & G/NT & 1/09 & $10 / 00$ & 1799 \\
\hline I/AF & G/DF & $1 / 99$ & $Q / \wedge \Delta$ & ميانكين \\
\hline
\end{tabular}

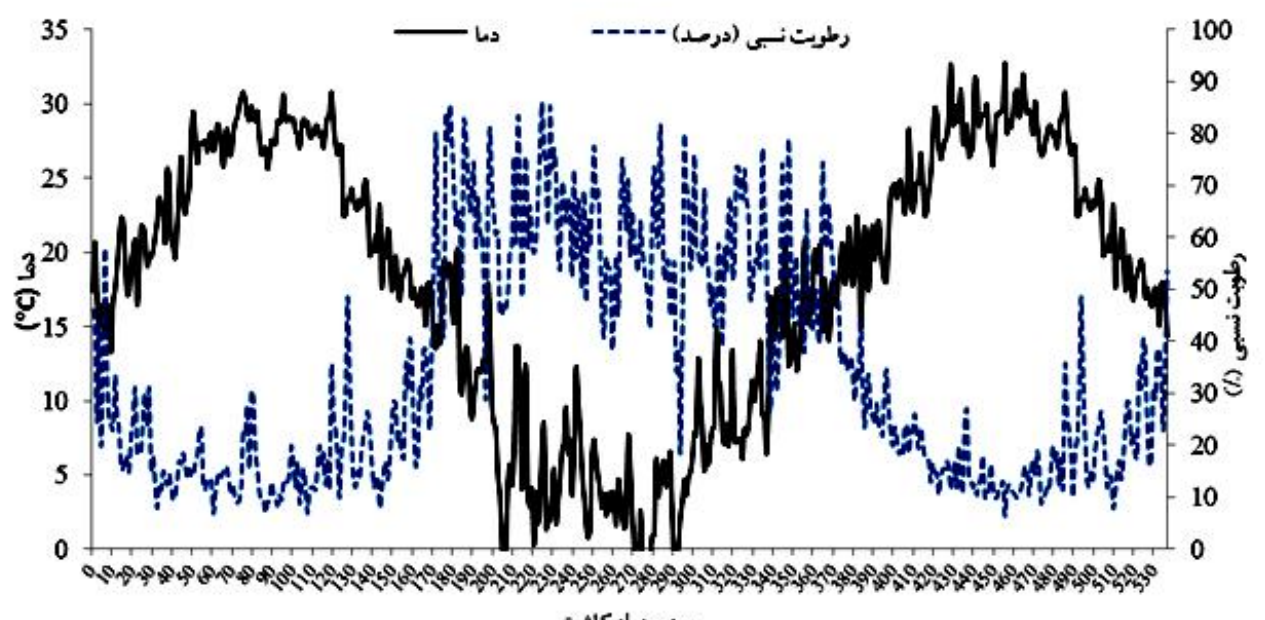

$$
\text { شكل r. تغييرات رطوبت نسبى و دما در دوره رشد كياه استويا }
$$



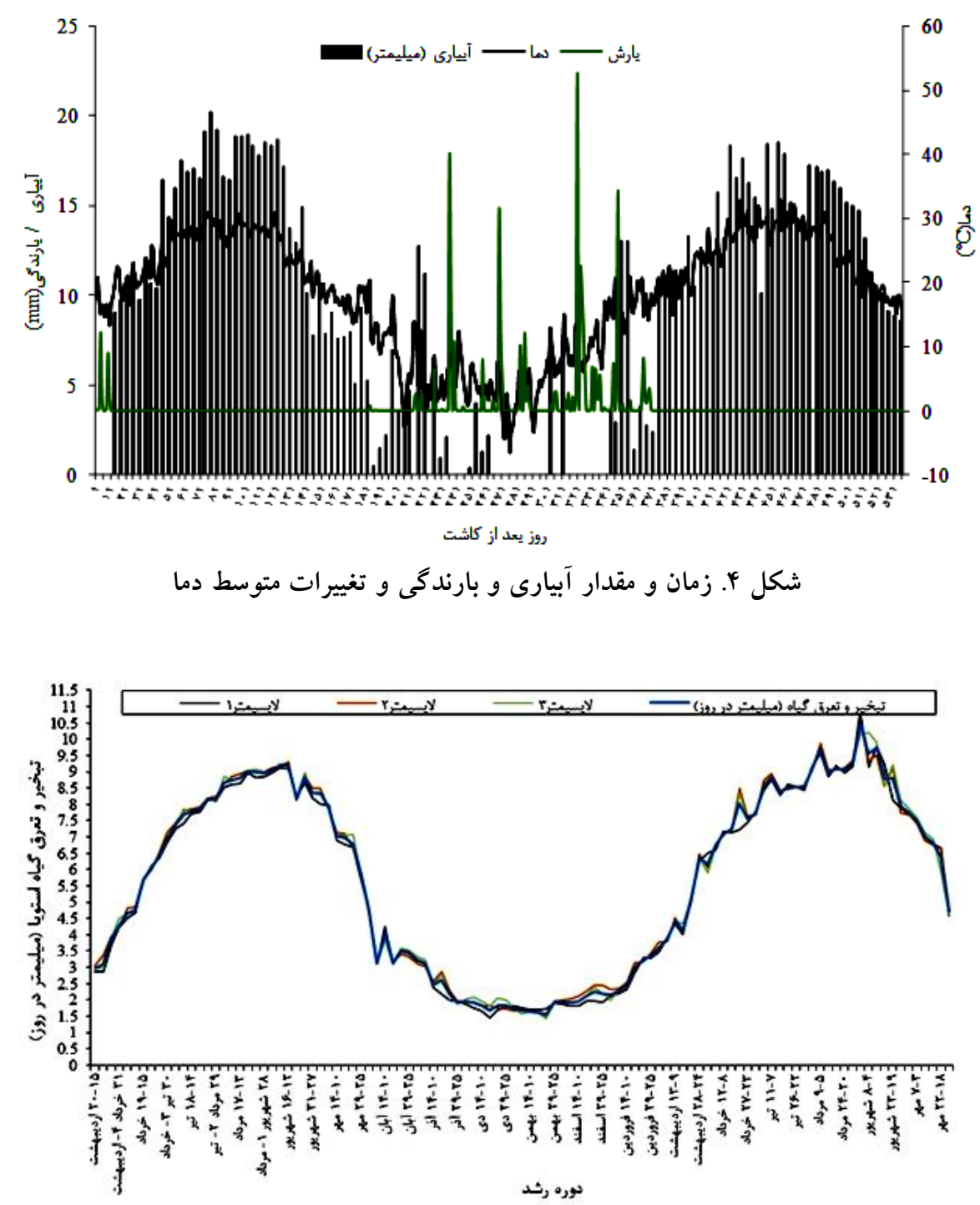

شكل ه. تغييرات تبخير - تعرق گياه استويا در سه لايسيمتر و متوسط آنها در طى دوره رشد گياه

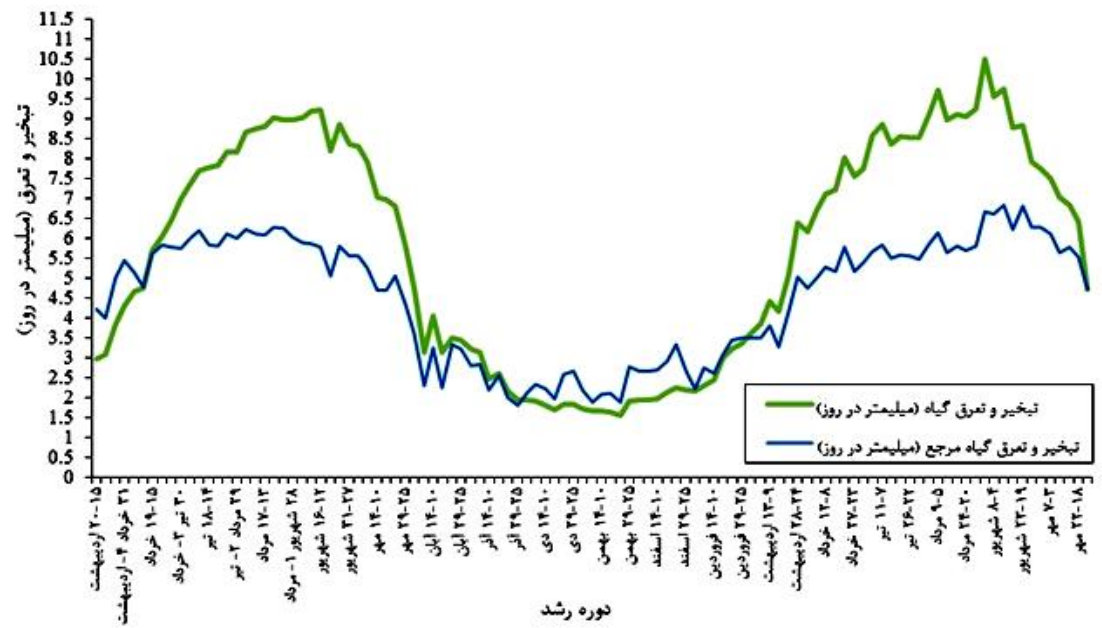

شكل צ. تغييرات تبخير - تعرق گياه استويا از لايسيمتر (ETC) و گياه مرجع (ETo) در دوره رشد گياه استويا 
نتايج تبخير - تعرق كياه (ETC) بهدست آمده از لايسيمترها طسى

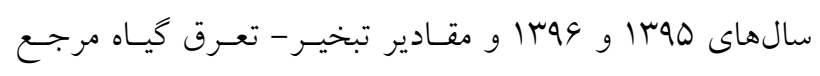

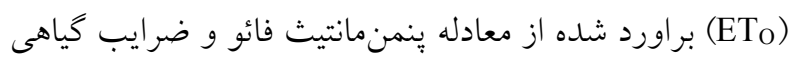

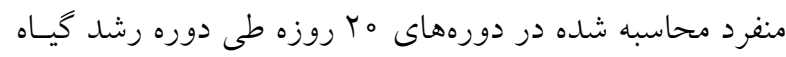
استويا در جدول (^) ارائه شده است. مقدار ETC در سـالهـاى آزمايش در مرحله ابتدايى بِايين است و سـسيس در طسى مرحلـه

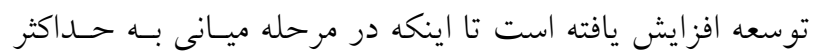

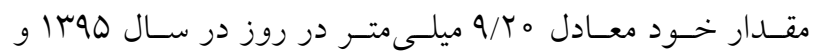

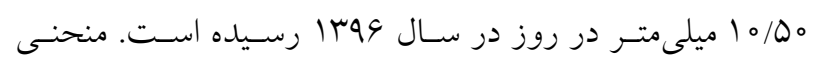

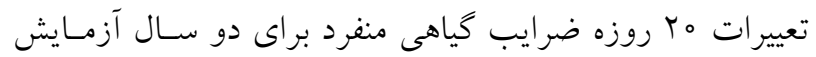
در شكل (1) ارائه شده است.

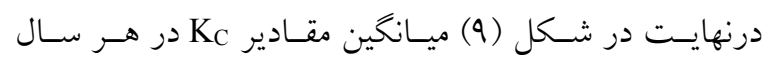

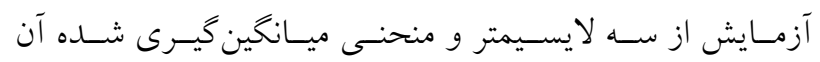
برحسب روزهاى رشد نشان داده شده است. مقادير KC در سال

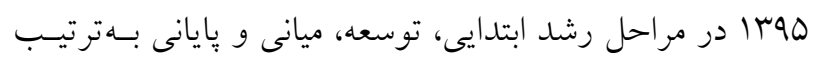

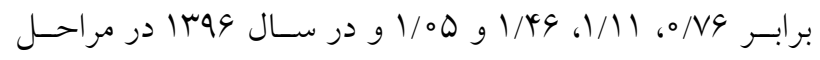

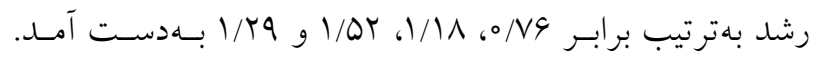

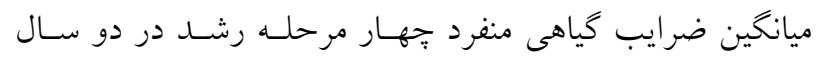

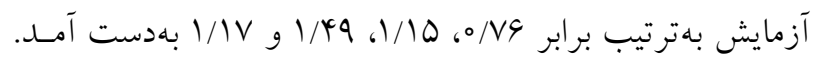

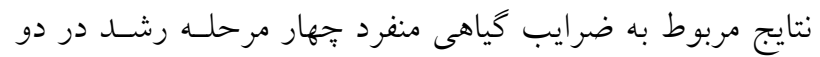
سال آزمايش در جلدول (9) ارائه شده است.

\section{نتيجه گيرى}

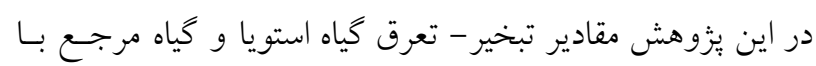

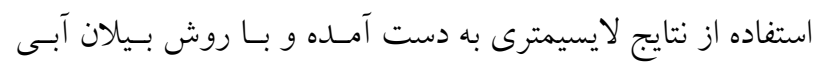

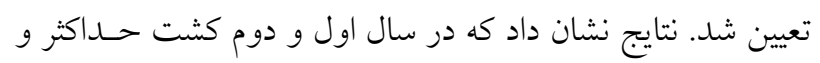

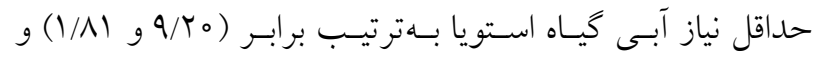

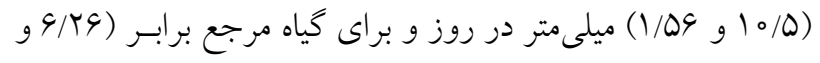

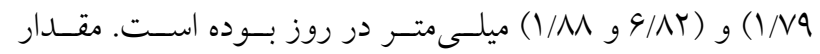

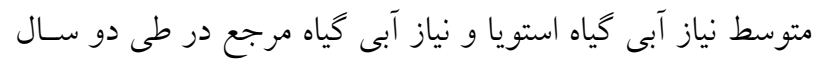

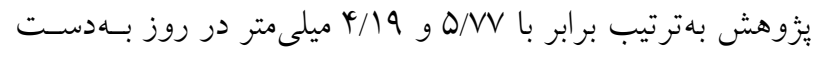

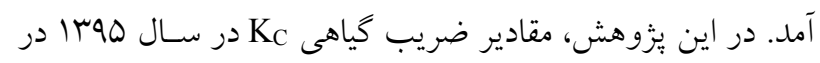

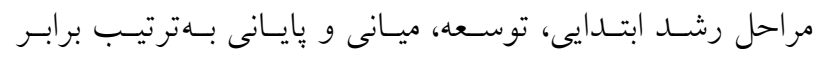

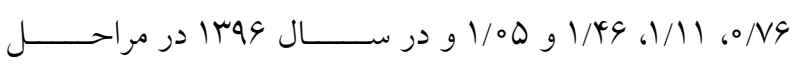

دورهها باشد. در آغاز و يايان دوره رشد ETO بيش از ETC بودهد

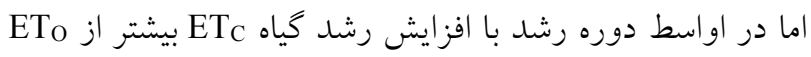

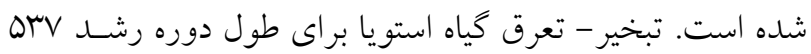

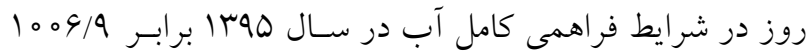

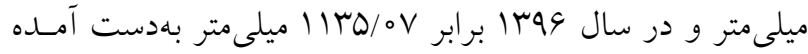

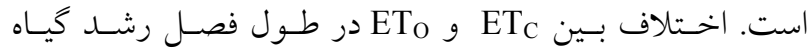

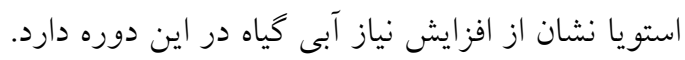

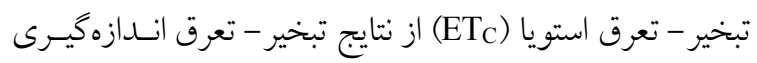

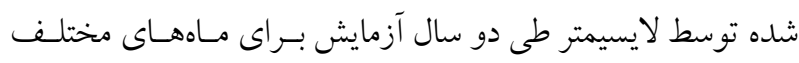

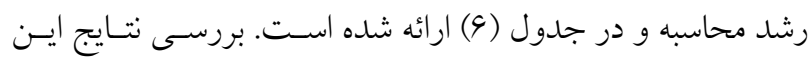

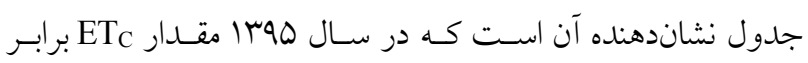

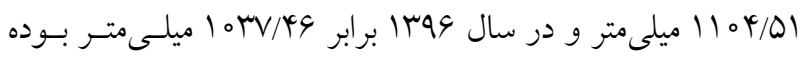

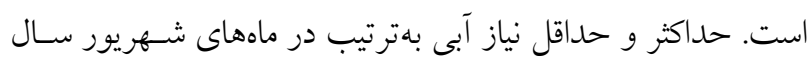

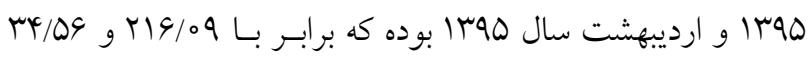

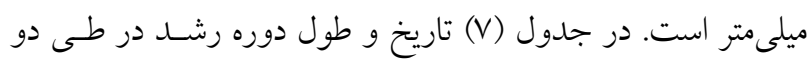
سال آزمايش و متوسط دوره رشــد در دو سـال ارائسه شـــه اسـت.

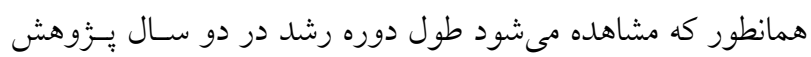

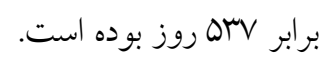

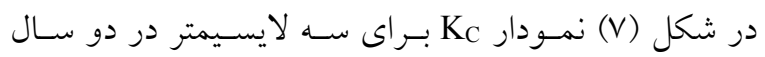

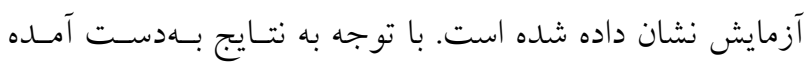
مىتوان نتيجه كرفت كه در مرحله ابتدايى كه رشــ كيـاه كـمـ و

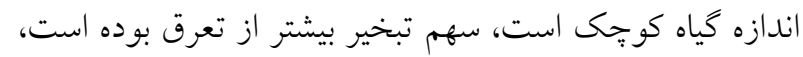

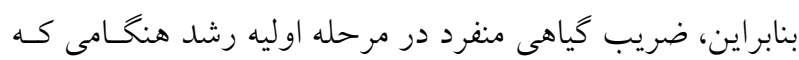

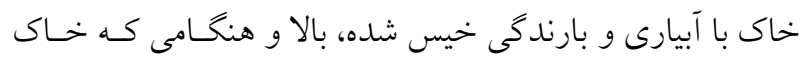
سطحى خشى است، بايين است. لذا مقدار تبخير - تعـرق گيساه

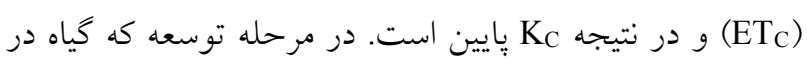

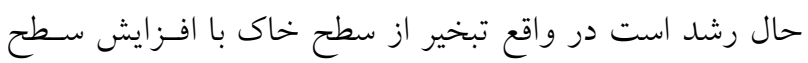

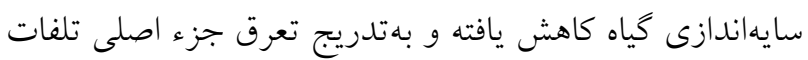

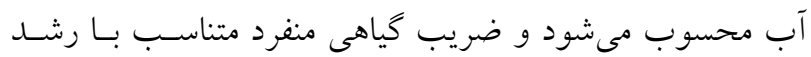

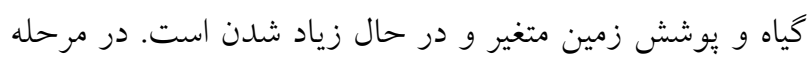

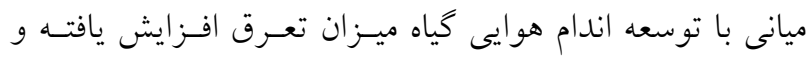

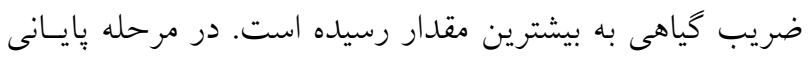

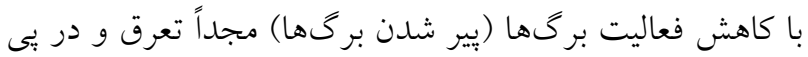

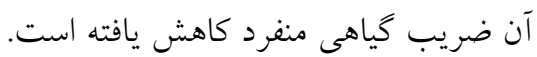


جدول 9. تبخير - تعرق ماهانه گياه استويا (ميلىمتر)

\begin{tabular}{|c|c|c|c|c|c|}
\hline 11499 & 1790 & ماه & 11499 & 11490 & ماه \\
\hline- & $\kappa \mu / \mu$ & |سفند & - & $M Y / \Delta \varphi$ & ارديبهشت \\
\hline$\Delta V / Q Y$ & - & فروردين & - & $111 / 91$ & خرداد \\
\hline $99 / T)$ & - & ارديبهشت & - & $19 \circ / \pi 1$ & تير \\
\hline $149 / 09$ & - & خرداد & - & $\mid \wedge r / 19$ & مرداد \\
\hline T०G/AT & - & تير & - & $519 / 09$ & شهريور \\
\hline $19 \% / 10$ & - & مرداد & - & $149 / 91$ & مهر \\
\hline $19 \pi / 01$ & - & شهريور & - & $W / 01$ & آبان \\
\hline \multirow[t]{3}{*}{$140 / 9 \mathrm{~V}$} & - & مهر & - & 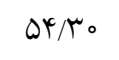 & آذر \\
\hline & & & - & rN/Q & دى \\
\hline & & & - & $r \Delta / \Delta r$ & بهمن \\
\hline
\end{tabular}

جدول V. طول مراحل مختلف رشد استويا در سالهاى آزمايش

\begin{tabular}{|c|c|c|c|c|c|}
\hline مدت & تاريخ & مرحله & مدت & تاريخ & مرحله \\
\hline V ل & 10 دى الى 9 اسفند & اوليه & ا آ روز & ها ارديبهشت الى ب خرداد & 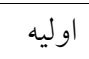 \\
\hline 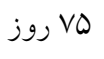 & 。ץ اسفند الى ז ا خرداد & توسعه & 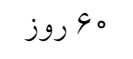 & ه خرداد الى Y مرداد & توسعه \\
\hline 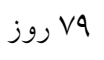 & rا خرداد الى & 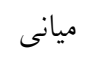 & ل اه ا روز & ب مرداد الى بَ آبان & ميانى \\
\hline 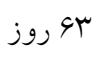 & مب مرداد الى •T مهر & بايانى & 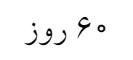 & ها آبان الى با 1 دى & يايانى \\
\hline
\end{tabular}

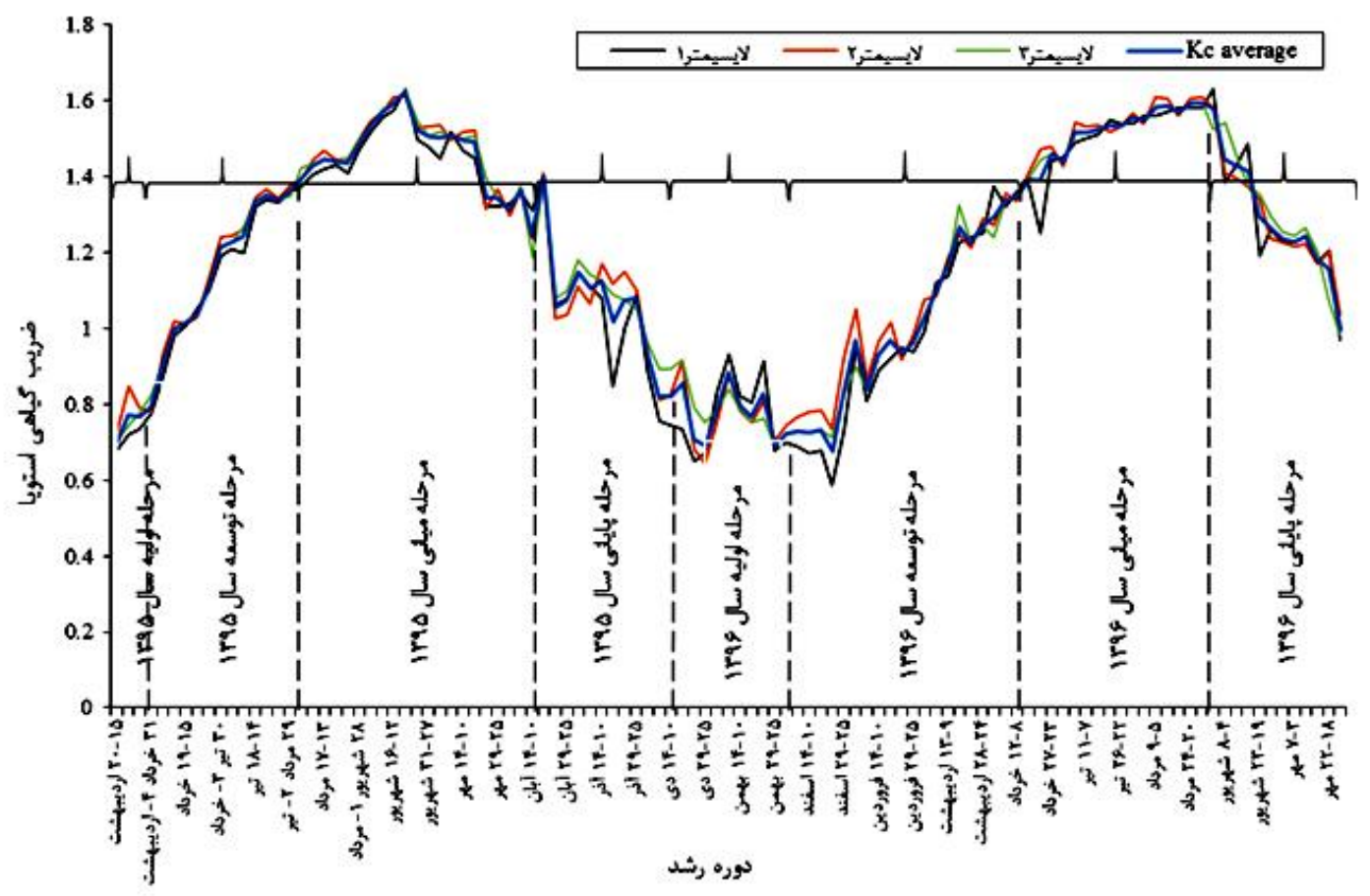

شكل V. تغييرات روزانه ضرايب گياهى منفرد استويا در سه لايسيمتر 


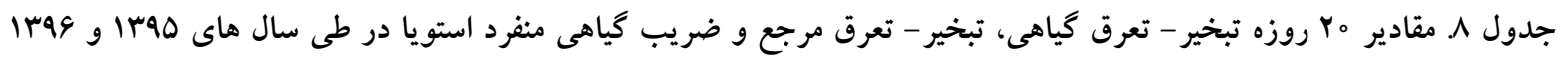

\begin{tabular}{|c|c|c|c|c|c|c|}
\hline \multicolumn{3}{|c|}{ سال وهץ| } & \multicolumn{3}{|c|}{ سال ه9ب1 } & \multirow{2}{*}{ دوره ه广 روزه } \\
\hline $\mathrm{Kc}$ & Eto & Etc & $\mathrm{Kc}$ & Eto & Etc & \\
\hline$\circ / V^{*}$ & $r / 90$ & $Y / Y^{\varphi}$ & $\circ / V 9$ & $1 / 99$ & $\Gamma / \Delta \Delta$ & 1 \\
\hline ./94 & $r / 9 V$ & $T / \Psi V$ & $0 / 99$ & سח/ه & $0 / Y q$ & r \\
\hline $1 / 01$ & $r / 4 \Lambda$ & $\Gamma / \Delta 1$ & $|/ r|$ & $0 / 9 \pi$ & V/IT & r \\
\hline $1 / T Y$ & $4 / 09$ & $0 / 01$ & ס & $0 / 94$ & $V / 91$ & $\varphi$ \\
\hline $1 / \pi \Delta$ & $Q / \circ D$ & $9 / 1 \circ$ & $1 / 4 r$ & $9 / 1 \mathrm{~V}$ & N/NI & 0 \\
\hline $1 / 40$ & $Q / \Delta \circ$ & $V / 9 V$ & $1 / 01$ & $9 / 01$ & $9 / 04$ & 9 \\
\hline 1/Qr & $0 / 91$ & $N / D V$ & $1 / 09$ & $\Delta / \Delta Y$ & $1 / 90$ & V \\
\hline $1 / \Delta V$ & $Q / V \Lambda$ & $Q / \circ V$ & $1 / 00$ & $0 / 0 \psi^{c}$ & $V / D Q$ & $\wedge$ \\
\hline $1 / 09$ & $0 / 9 \Lambda$ & $q / 4 \wedge$ & $1 / \mu^{4}$ & r/Ar & $0 / 1 T$ & 9 \\
\hline $1 / \pi q$ & $9 / 91$ & $Q / Y Y$ & $1 / 1 \wedge$ & $r / 01$ & r/Or & 10 \\
\hline $1 / T Q$ & $9 / 0 \mathrm{~V}$ & $V / \Delta D$ & $1 / 10$ & $T / \varphi_{0}$ & r/A & 11 \\
\hline \multirow[t]{4}{*}{$1 / 1 r$} & $Q / M^{K}$ & $0 / 9 \Lambda$ & $\circ / 9 V$ & $T / \circ D$ & $1 / 91$ & ir \\
\hline & - & - & $\circ / V G$ & T/TG & $1 / v 9$ & r \\
\hline & - & - & $\circ / \wedge 1$ & $T / 09$ & $1 / 9 \mathrm{~V}$ & 14 \\
\hline & - & - & $\circ /{ }^{4}$ & $r / \Delta^{\circ}$ & 1/N & 10 \\
\hline
\end{tabular}

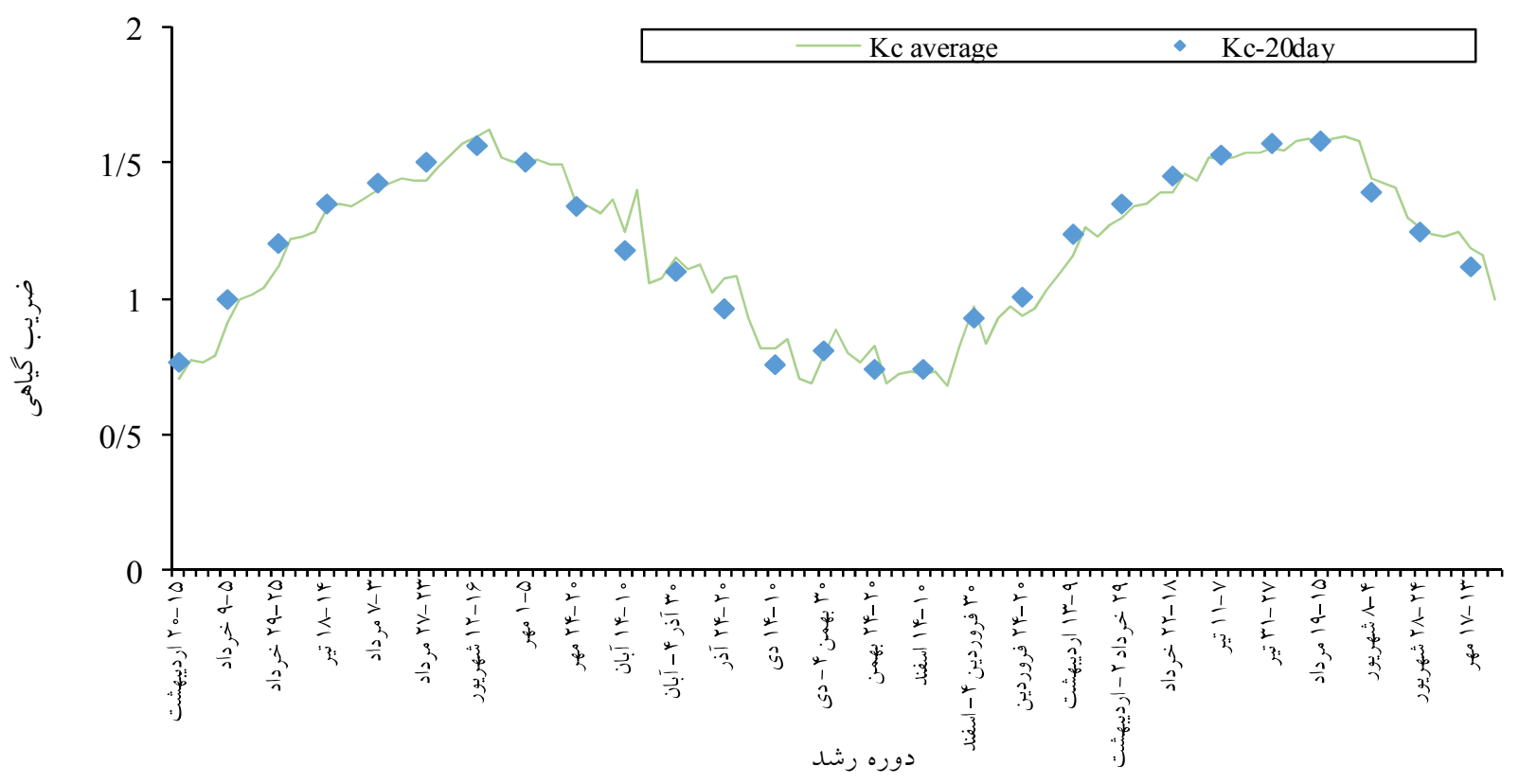

شكل ^ـ ضرايب گياهى منفرد روزانه و بيست روزه استويا در مراحل رشد 


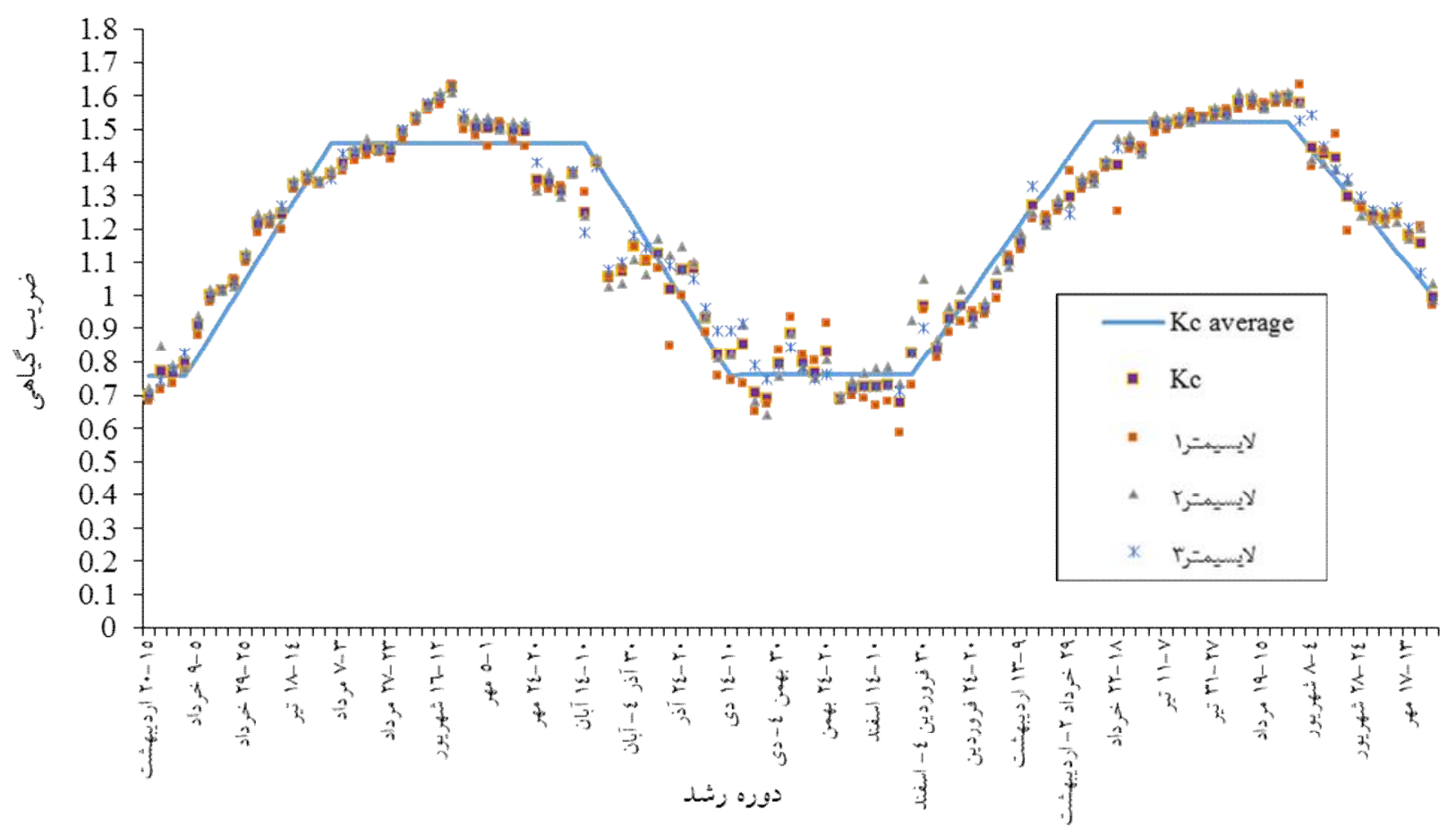

شكل 9.

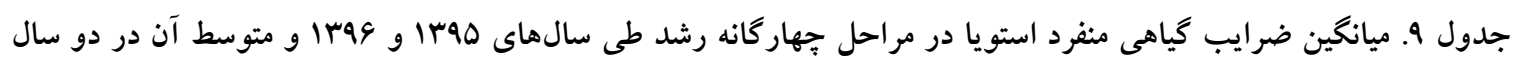

\begin{tabular}{|c|c|c|c|c|}
\hline مرحله بِيانى & مرحله ميانى & مرحله توسعه & مرحله ابتد ايى & سال \\
\hline $1 / 00$ & $1 / 49$ & $1 / 11$ & ०NG & 11490 \\
\hline $1 / 79$ & $1 / D T$ & $1 / 1 \wedge$ & ०NG & 1499 \\
\hline 94 & $9 r$ & $9 \Lambda$ & $\uparrow \wedge$ & طول متوسط هر دوره \\
\hline $1 / 1 V$ & $1 / 49$ & $1 / 10$ & ०NG & ميانگين \\
\hline
\end{tabular}

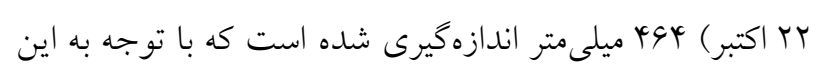

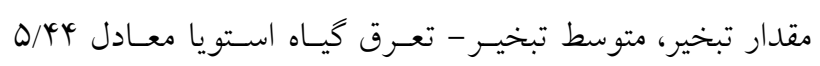

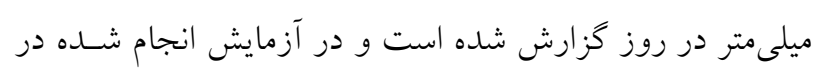

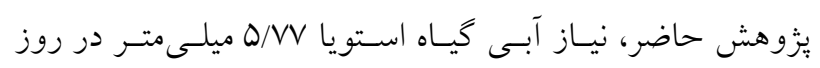

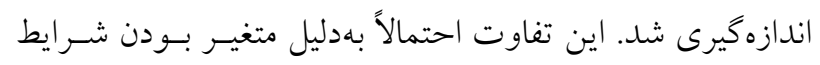

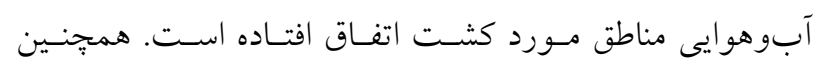

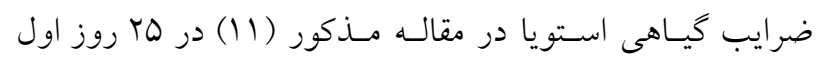

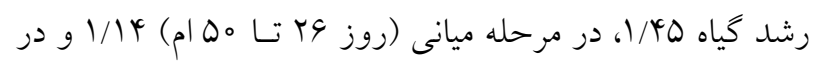

رشد بهترتيب برابـر /V9ه، 1/11، 1/0r و 1/R9 بـهدسـت آمـد.

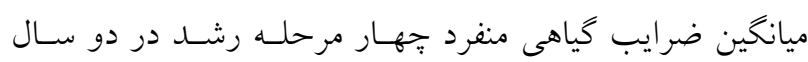

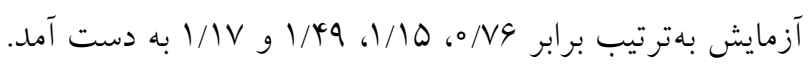
در رابطه با نياز آبسى و تعيسين ضـرايب كيـاهى اسـتويا تـاكنون

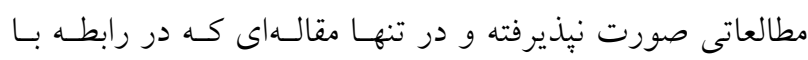

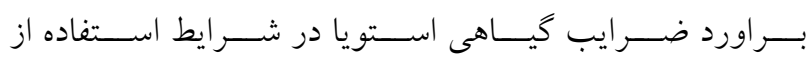

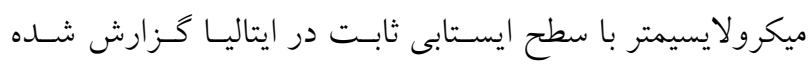

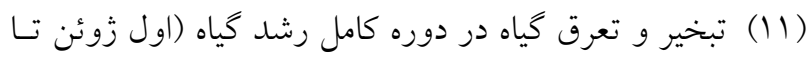




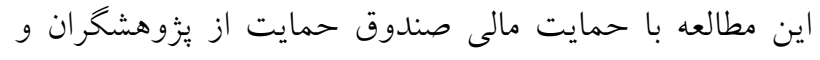

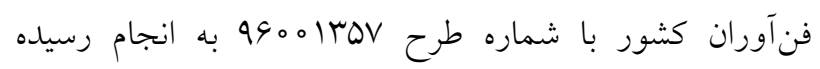

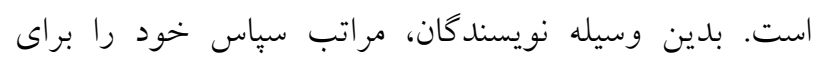

حمايت مالى انجام شده اعلام مى دارند.

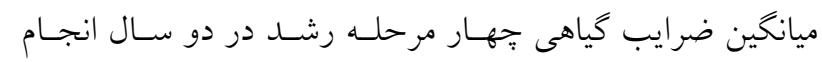

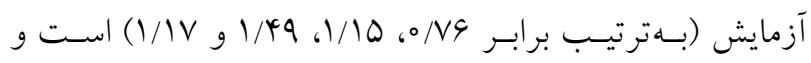

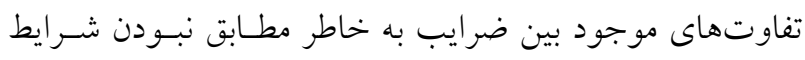

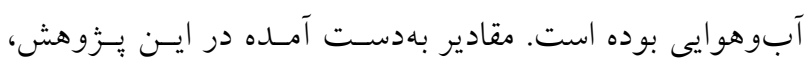

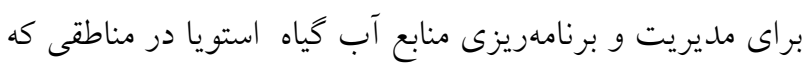

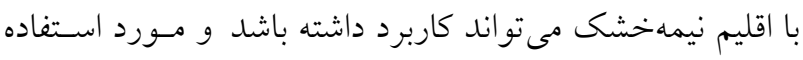

يزّوهشخر ان، طراحان و مهندسين مشاور قرار گيرد.

\section{منابع مورد استفاده}

1. Abedinpour, M. 2015. Evaluation of growth-stage-specific crop coefficients of maize using weighing lysimeter. Soil \& Water Research 10(2): 99-104.

2. Azizi-Zohan, A., A. A. Kamgar-Haghighi and A. R. Sepaskhah. 2008. Crop and pan coefficients for saffron in a semiarid region of Iran. Journal of Arid Environments 72: 270-278.

3. Boromand Nasab, S., H. Kashkoli and M. Khaledian. 2006. Determination of water requirement and sugar coefficients of sugarcane in Haft Tapeh agro-industrial lands of Khuzestan. In: Proceeding of the National Conference on Irrigation and Drainage Network Management. Faculty of Water Engineering, Shahid Chamran University of Ahvaz. (In Farsi).

4. Bossie, M., K. Tilahun and T. Hordofa. 2009. Crop coefficient and evaptranspiration of onion at Awash Melkassa, Central Rift Valley of Ethiopia. Irrigation and Drainage System 23: 1-10.

5. Dewidar, A. Z., A. Ben Abdallah, Y. Al-Fuhaid and B. Essafi. 2015. Lysimeter based water requirements and crop coefficient of surface drip-irrigated date palm in Saudi Arabia. International Research Journal of Agricultural Science and Soil Science 5(7): 173 -182.

6. Fronza, D. and M. Vinícius Folegatti. 2003. water consumption of the Estevia (Stevia rebaudiana Bertoni) crop estimated through microlysimeter. Journal of Scientia Agricola 60(3): 595-599.

7. Ghamarnia, H., M. Jafari Zadeh, E. Miri and M. Ghobadi. 2011. Estimation of coriander vegetation coefficient in semi-arid climate region. Journal of Water and Irrigation Management 1(2): 83-73. (In Farsi)

8. Ghamarnia, H., E. Miri, M. Jafari Zadeh and M. Ghobadi. 2011. Determination of growth factor of black seed at different growth stages by lysimetry method. Journal of Water Research in Agriculture 2(2): 145-133. (In Farsi).

9. Lia J., J. Cuia, R. Chena, P. Yanga, Y. Wub, Sh.Chaia and F. Ma . 2016. Evapotranspiration and crop coefficient of drip-irrigated winter wheat in China's Xinjiang Province. Science Asia 42: 303-31.

10. Kafi, M. and A. Kashmir. 2011. Study of Yield Components of yield and indigenous cumin under drought and salinity conditions, Journal of Horticultural Sciences (25): 253-327. (In Farsi).

11. Li, S., S. Kang, F. Li and L. Zhang. 2008. Evapotranspiration and crop coefficient of spring maize withplastic mulch using eddy covariance in northwest China. Agricultural Water Management 95: 1214-1222.

12. Liu, Y. and Y. Luo. 2010. A consolidated evaluation of the FAO-56 dual crop coefficient approach using the lysimeter data in the North China Plain. Agricultural Water Management 97(1): 31-40.

13. Rahimian, M. H. and A. S. Kakhaki. 2007. Water requirement of cotton and its coefficient of vegetation by lysimeter method in Kashmar region. In: Proceeding of the $9^{\text {th }}$ Seminar on Irrigation and Evaporation Reduction, Kerman. (In Farsi).

14. Reihani, N., A. Khashie Siouki, M. Rashid and F. Hadi. 2015. Estimation of cumin vegetation coefficient at different growth stages by lysimeter method in Birjand region. Journal of Water and Soil (Agricultural Science and Technology) 29 (5): 1056-1047. (In Farsi).

15. Shukla, S., F. Jaber, S. Srivastava and J. Knowles. 2007. Water Use and Crop Coefficient for Watermelon in Southwest Florida in USA. Agricultural and Biological Engineering Depatment.

16. Zare Abyaneh, H., M. Bayat Varkeshi, A. Ghasemi, S. Marofi and R. Amiri Chayjan. 2011. Determination of water requirement, single and dual crop coefficient of garlic (Allium sativum) in the cold semi-arid climate. Australian Journal of Crop Science 5(8): 1050-1054. 
17. Zhang, B. Z., Y. Liu, D. Xu, N. N. Zhao, B. Lei, R. D. Rosa, P. Paredes, T. A. Paço and L. S. Pereira. 2013. The dual crop coefficient approach to estimate and partitioning evapotranspiration of the winter wheat-summer maize crop sequence in North China Plain. Irrigation Science 31: 1303-16. 


\title{
Estimated Water Requirements and Stevia Rebaudiana Bertoni Crop Coefficient in Semi-Dry Climate under Lysimetric Conditions
}

\author{
Z. Jalili ${ }^{1}$, H. Ghamarnia ${ }^{1^{*}}$ and D. Kahrizi ${ }^{2}$
}

(Received: February 14-2018 ; Accepted: March 24-2018)

\begin{abstract}
Exactly estimating of water requirement is essential for water balance studies, design and management of irrigation systems and water resources management. Because of limited soil and water resources in Iran, for optimal use of water resources in the agricultural sector, it is necessary to determine the amount of water requirement by different plants in different climatological conditions. In order to determine the water requirement and crop coefficients of Stevia, six lysimeter numbers were used in three replications for stevia and reference plant (grass). The reference Stevia plant evapotranspiration was measured on a daily basis. The results showed that during the 537 day period of Stevia cultivation, the maximum and minimum water requirement in the first and second year of cultivation was respectively 9.85 and $1.69 \mathrm{~mm}$ per day, and for the reference plant was obtained as 6.54 and $1.84 \mathrm{~mm}$ per day. In this study, the Kc coefficients in initial, development, intermediate and final stages of growth in 2016 were $0.76,1.11,1.46$ and 1.05 and in 2017 at growth stages, were $0.76,1.18,1.52$ and 1.29 respectively. The average of individual Stevia plant growth factors for four growth stages in two years of research was obtained as $0.76,1.15,1.49$, and 1.17 , respectively.
\end{abstract}

Keywords: Evapotranspiration, Reference Plants, Research Farm, Stevia

1. Department of Water Engineering, Compass of Agriculture and Natural Resources, Razi University, Kermanshah, Iran.

2. Department of Horticulture, Compass of Agriculture and Natural Resources, Razi University, Kermanshah, Iran.

*: Corresponding Author, Email: hghamarnia@razi.ac.ir 